UNIVERSITÉ CLERMONT AUVERGNE

UFR DE MÉDECINE ET DES PROFESSIONS PARAMÉDICALES

\author{
THÈSE D’EXERCICE
}

pour le

DIPLÔME D’ÉTAT DE DOCTEUR EN MÉDECINE

par

\title{
GRAS Damien
}

Présentée et soutenue publiquement le 29 avril 2021

\section{Supplémentation en créatine et $\mathrm{VO}_{2} \mathrm{max}$ : Revue systématique et méta-analyse}

Président du jury : Monsieur COUDEYRE Emmanuel, Professeur, CHU ClermontFerrand, Médecine Physique et Réadaptation

Directeur de thèse : Monsieur DUTHEIL Frédéric, Professeur, CHU ClermontFerrand, Santé Travail Environnement

Membre du jury : Madame LANHERS Charlotte, Docteur en Médecine Physique et Réadaptation

Membre du jury : Monsieur Bruno PEREIRA, Biostatisticien, CHU ClermontFerrand, Direction de la Recherche Clinique et de l'Innovation 
UNIVERSITÉ CLERMONT AUVERGNE

UFR DE MÉDECINE ET DES PROFESSIONS PARAMÉDICALES

\author{
THÈSE D’EXERCICE
}

pour le

DIPLÔME D’ÉTAT DE DOCTEUR EN MÉDECINE

par

\title{
GRAS Damien
}

Présentée et soutenue publiquement le 29 avril 2021

\section{Supplémentation en créatine et $\mathrm{VO}_{2} \mathrm{max}$ : Revue systématique et méta-analyse}

Président du jury : Monsieur COUDEYRE Emmanuel, Professeur, CHU ClermontFerrand, Médecine Physique et Réadaptation

Directeur de thèse : Monsieur DUTHEIL Frédéric, Professeur, CHU ClermontFerrand, Santé Travail Environnement

Membre du jury : Madame LANHERS Charlotte, Docteur en Médecine Physique et Réadaptation

Membre du jury : Monsieur Bruno PEREIRA, Biostatisticien, CHU ClermontFerrand, Direction de la Recherche Clinique et de l'Innovation 


\section{UNIVERSITE CLERMONT AUVERGNE}

PRESIDENTS HONORAIRES

UNIVERSITE D'AUVERGNE

PRESIDENTS HONORAIRES

UNIVERSITE BLAISE PASCAL

PRESIDENT DE L'UNIVERSITE et PRESIDENT DU

CONSEIL ACADEMIQUE PLENIER

PRESIDENT DU CONSEIL ACADEMIQUE RESTREINT VICE-PRESIDENT DU CONSEIL D'ADMINISTRATION VICE-PRESIDENT DE LA COMMISSION DE LA RECHERCHE

VICE PRESIDENTE DE LA COMMISSION DE LA FORMATION ET DE LA VIE UNIVERSITAIRE DIRECTEUR GENERAL DES SERVICES
: JOYON Louis

: DOLY Michel

: TURPIN Dominique

VEYRE Annie

: DULBECCO Philippe

: ESCHALIER Alai

: CABANES Pierre : FONTAINE Jacques : BOUTIN Christian : MONTEIL Jean-Marc : ODOUARD Albert : LAVIGNOTTE Nadine

: BERNARD Mathias : DEQUIEDT Vianney : WILLIAMS Benjamin : HENRARD Pierre

PEYRARD Françoise : PAQUIS François

$\diamond \diamond \diamond \diamond \diamond$

UFR DE MEDECINE ET DES PROFESSIONS PARAMEDICALES

DOYENS HONORAIRES

DOYEN

RESPONSABLE ADMINISTRATIVE
: DETEIX Patrice : CHAZAL Jean

: CLAVELOU Pierre : ROBERT Gaëlle 


\section{LISTE DU PERSONNEL ENSEIGNANT}

\section{PROFESSEURS HONORAIRES :}

MM. BACIN Franck - BEGUE René-Jean - BOUCHER Daniel - BOURGES Michel - BUSSIERE JeanLouis - CANO Noël - CASSAGNES Jean - CATILINA Pierre - CHABANNES Jacques - CHAZAL Jean - CHIPPONI Jacques - CHOLLET Philippe - COUDERT Jean - DASTUGUE Bernard DAUPLAT Jacques - DECHELOTTE Pierre - DEMEOCQ François - DE RIBEROLLES Charles ESCANDE Georges -Mme FONCK Yvette - MM. GENTOU Claude -GLANDDIER Gérard - Mme GLANDDIER Phyllis - M. JACQUETIN Bernard - Mme LAVARENNE Jeanine - MM. LAVERAN Henri - LESOURD Bruno - LEVAI Jean-Paul - MAGE Gérard - MALPUECH Georges - MARCHEIX Jean-Claude - MICHEL Jean-Luc - MOLINA Claude - MONDIE Jean-Michel - PERI Georges - PETIT Georges - PHILIPPE Pierre - PLAGNE Robert - PLANCHE Roger - PONSONNAILLE Jean - REY Michel - Mme RIGAL Danièle - MM. ROZAN Raymond - SCHOEFFLER Pierre - SIROT Jacques SOUTEYRAND Pierre - TANGUY Alain - TERVER Sylvain - THIEBLOT Philippe - TOURNILHAC Michel - VANNEUVILLE Guy - VIALLET Jean-François - Mlle VEYRE Annie

\section{PROFESSEURS EMERITES :}

MM. BEYTOUT Jean - BOITEUX Jean-Paul - BOMMELAER Gilles - CHAMOUX Alain - DETEIX Patrice - DUBRAY Claude - ESCHALIER Alain - IRTHUM Bernard - KEMENY Jean-Louis - LABBE André - Mme LAFEUILLE Hélène - MM. LEMERY Didier - LUSSON Jean-René - RIBAL Jean-Pierre

\section{PROFESSEURS DES UNIVERSITES-PRATICIENS HOSPITALIERS}

\section{PROFESSEURS DE CLASSE} EXCEPTIONNELLE

M. VAGO Philippe

M. AUMAITRE Olivier

M. LABBE André

M. AVAN Paul

M. DURIF Franck

M. BOIRE Jean-Yves

M. BOYER Louis

M. POULY Jean-Luc

M. CANIS Michel

Mme PENAULT-LLORCA Frédérique

M. BAZIN Jean-Etienne

M. BIGNON Yves Jean

M. BOIRIE Yves

M. CLAVELOU Pierre

M. DUBRAY Claude

M. GILAIN Laurent

M. LEMAIRE Jean-Jacques

M. CAMILLERI Lionel
Histologie-Embryologie Cytogénétique

Médecine Interne

Pédiatrie

Biophysique et Traitement de l'Image

Neurologie

Biostatistiques, Informatique Médicale et

Technologies de Communication

Radiologie et Imagerie Médicale option Clinique

Gynécologie et Obstétrique

Gynécologie-Obstétrique

Anatomie et Cytologie Pathologiques

Anesthésiologie et Réanimation Chirurgicale

Cancérologie option Biologique

Nutrition Humaine

Neurologie

Pharmacologie Clinique

O.R.L.

Neurochirurgie

Chirurgie Thoracique et Cardio-Vasculaire 
M. DAPOIGNY Michel

M. LLORCA Pierre-Michel

M. PEZET Denis

M. SOUWEINE Bertrand

M. BOISGARD Stéphane

Mme DUCLOS Martine

M. SCHMIDT Jeannot

M. BERGER Marc

M. GARCIER Jean-Marc

M. ROSSET Eugénio

M. SOUBRIER Martin
Gastro-Entérologie

Psychiatrie d'Adultes

Chirurgie Digestive

Réanimation Médicale

Chirurgie Orthopédique et Traumatologie

Physiologie

Thérapeutique

Hématologie

Anatomie-Radiologie et Imagerie Médicale

Chirurgie Vasculaire

Rhumatologie

\section{PROFESSEURS DE}

lère CLASSE

M. CAILLAUD Denis

M. VERRELLE Pierre

M. CITRON Bernard

M. D'INCAN Michel

Mme JALENQUES Isabelle

Mle BARTHELEMY Isabelle

M. GERBAUD Laurent

M. TAUVERON Igor

M. MOM Thierry

M. RICHARD Ruddy

M. RUIVARD Marc

M. SAPIN Vincent

M. BAY Jacques-Olivier

M. COUDEYRE Emmanuel

Mme GODFRAIND Catherine

M. ABERGEL Armando

M. LAURICHESSE Henri

M. TOURNILHAC Olivier

M. CHIAMBARETTA Frédéric

M. FILAIRE Marc

M. GALLOT Denis

M. GUY Laurent

M. TRAORE Ousmane

M. ANDRE Marc

M. BONNET Richard

M. CACHIN Florent

M. COSTES Frédéric

M. FUTIER Emmanuel

Mme HENG Anne-Elisabeth

M. MOTREFF Pascal

Mme PICKERING Gisèle

M. RABISCHONG Benoît
Pneumo-phtisiologie

Radiothérapie option Clinique

Cardiologie et Maladies Vasculaires

Dermatologie -Vénéréologie

Psychiatrie d'Adultes

Chirurgie Maxillo-Faciale

Epidémiologie, Economie de la Santé et

Prévention

Endocrinologie et Maladies Métaboliques

Oto-Rhino-Laryngologie

Physiologie

Médecine Interne

Biochimie et Biologie Moléculaire

Cancérologie

Médecine Physique et de Réadaptation

Anatomie et Cytologie Pathologiques

Hépatologie

Maladies Infectieuses et Tropicales

Hématologie

Ophtalmologie

Anatomie - Chirurgie Thoracique et Cardio-

Vasculaire

Gynécologie-Obstétrique

Urologie

Hygiène Hospitalière

Médecine Interne

Bactériologie, Virologie

Biophysique et Médecine Nucléaire

Physiologie

Anesthésiologie-Réanimation

Néphrologie

Cardiologie

Pharmacologie Clinique

Gynécologie Obstétrique 


\begin{tabular}{ll} 
Mme & CREVEAUX Isabelle \\
M. & FAICT Thierry \\
Mme & KANOLD LASTAWIECKA \\
& Justyna \\
M. & TCHIRKOV Andréï \\
M. & CORNELIS François \\
M. & DESCAMPS Stéphane \\
M. & POMEL Christophe \\
M. & CANAVESE Fédérico \\
M. & LESENS Olivier \\
M. & AUTHIER Nicolas \\
M. & BROUSSE Georges \\
M. & BUC Emmanuel \\
M. & CHABROT Pascal \\
M. & LAUTRETTE Alexandre \\
M. & AZARNOUSH Kasra \\
Mme & BRUGNON Florence \\
& \\
Mme & HENQUELL Cécile \\
M. & ESCHALIER Romain \\
M. & MERLIN Etienne \\
Mme & TOURNADRE Anne \\
M. & DURANDO Xavier \\
M. & DUTHEIL Frédéric \\
Mme & FANTINI Maria Livia \\
M. & SAKKA Laurent \\
M. & BOURDEL Nicolas \\
M. & GUIEZE Romain \\
M. & POINCLOUX Laurent \\
M. & SOUTEYRAND Géraud \\
M. & EVRARD Bertrand \\
M. & POIRIER Philippe \\
& \\
\hline
\end{tabular}

Biochimie et Biologie Moléculaire Médecine Légale et Droit de la Santé Pédiatrie

Cytologie et Histologie

Génétique

Chirurgie Orthopédique et Traumatologique

Cancérologie - Chirurgie Générale

Chirurgie Infantile

Maladies Infectieuses et Tropicales

Pharmacologie Médicale

Psychiatrie Adultes/Addictologie

Chirurgie Digestive

Radiologie et Imagerie Médicale

Néphrologie Réanimation Médicale

Chirurgie Thoracique et Cardiovasculaire

Biologie et Médecine du Développement et de la

Reproduction

Bactériologie Virologie

Cardiologie

Pédiatrie

Rhumatologie

Cancérologie

Médecine et Santé au Travail

Neurologie

Anatomie - Neurochirurgie

Gynécologie-Obstétrique

Hématologie

Gastroentérologie

Cardiologie

Immunologie

Parasitologie et Mycologie

\section{PROFESSEURS DES UNIVERSITES}

$\begin{array}{lll}\text { M. } & \text { CLEMENT Gilles } & \text { Médecine Générale } \\ \text { Mme } & \text { MALPUECH-BRUGERE Corinne } & \text { Nutrition Humaine } \\ \text { M. } & \text { VORILHON Philippe } & \text { Médecine Générale }\end{array}$

\section{PROFESSEURS ASSOCIES DES UNIVERSITES}

$\begin{array}{lll}\text { Mme } & \text { BOTTET-MAULOUBIER Anne } & \text { Médecine Générale } \\ \text { M. } & \text { CAMBON Benoît } & \text { Médecine Générale } \\ \text { M. } & \text { TANGUY Gilles } & \text { Médecine Générale }\end{array}$




\section{MAITRES DE CONFERENCES} HORS CLASSE

Mme CHAMBON Martine

Mme BOUTELOUP Corinne
Bactériologie Virologie

Nutrition

\section{MAITRES DE CONFERENCES DE} lère CLASSE

M. MORVAN Daniel

Mle GOUMY Carole

Mme FOGLI Anne

Mle GOUAS Laetitia

M. MARCEAU Geoffroy

Mme MINET-QUINARD Régine

M. ROBIN Frédéric

Mle VERONESE Lauren

M. DELMAS Julien

Mle MIRAND Audrey

M. OUCHCHANE Lemlih

M. LIBERT Frédéric

Mle COSTE Karen

Mle AUMERAN Claire

Mme CASSAGNES Lucie

M. LEBRETON Aurélien

M. BUISSON Anthony
Biophysique et Traitement de l'Image

Cytologie et Histologie, Cytogénétique

Biochimie Biologie Moléculaire

Cytologie et Histologie, Cytogénétique

Biochimie Biologie Moléculaire

Biochimie Biologie Moléculaire

Bactériologie

Cytologie et Histologie, Cytogénétique

Bactériologie

Bactériologie Virologie

Biostatistiques, Informatique Médicale et

Technologies de Communication

Pharmacologie Médicale

Pédiatrie

Hygiène Hospitalière

Radiologie et Imagerie Médicale

Hématologie

Gastroentérologie

\section{MAITRES DE CONFERENCES DE}

2ème CLASSE

Mme PONS Hanaë

M. JABAUDON-GANDET Matthieu

M. BOUVIER Damien

COLL Guillaume

Mme SARRET Catherine

M. MAQDASY Salwan

Mme NOURRISSON Céline
Biologie et Médecine du Développement et de la Reproduction

Anesthésiologie - Réanimation Chirurgicale

Biochimie et Biologie Moléculaire

Neurochirurgie

Pédiatrie

Endocrinologie, Diabète et Maladies

Métaboliques

Parasitologie - Mycologie 
Mme VAURS-BARRIERE Catherine

M. BAILLY Jean-Luc

Mle AUBEL Corinne

M. BLANCHON Loïc

Mle GUILLET Christelle

M. BIDET Yannick

M. MARCHAND Fabien

M. DALMASSO Guillaume

M. SOLER Cédric

M. GIRAUDET Fabrice

Mme VAILLANT-ROUSSEL Hélène

Mme LAPORTE Catherine

M. LOLIGNIER Stéphane

Mme MARTEIL Gaëlle

M. PINEL Alexandre

M. PIZON Frank
Biochimie Biologie Moléculaire

Bactériologie Virologie

Oncologie Moléculaire

Biochimie Biologie Moléculaire

Nutrition Humaine

Oncogénétique

Pharmacologie Médicale

Bactériologie

Biochimie Biologie Moléculaire

Biophysique et Traitement de l'Image

Médecine Générale

Médecine Générale

Neurosciences - Neuropharmacologie

Biologie de la Reproduction

Nutrition Humaine

Santé Publique

\section{MAITRES DE CONFERENCES ASSOCIES DES UNIVERSITES}

M. BERNARD Pierre

Mme ESCHALIER Bénédicte

Mme RICHARD Amélie

M. TESSIERES Frédéric
Médecine Générale

Médecine Générale

Médecine Générale

Médecine Générale 


\section{Remerciements}

A mes parents, à ma famille, pour leur amour et leur dévotion, j'espère que vous serez fiers de ce travail.

A mon frère, qui partage la même passion sportive et professionnelle, partenaire d'entraînement et de travail tout au long des études de médecine et maintenant interne en anatomie cytologie pathologique, courage pour ta thèse.

A mes amis, pour leur joie de vivre et les moments passés ensembles toujours appréciés.

A mes coachs d'athlétisme, qui m'ont aidé à conjuguer objectifs professionnels et sportifs, et avec lesquels je garderai toujours en souvenir de grands moments sportifs et de vie et des stages inoubliables sur tous les continents.

A mes co-internes que je remercie pour leur bonne humeur, pour les partages d'expérience enrichissants, et pour leur aide quand le temps jouait contre moi pour finir ce travail.

Aux professeurs et médecins qui ont guidés mes pas et façonné mes connaissances et compétences médicales par leur enseignement.

A tous les athlètes, qui pourraient tirer des enseignements de ce travail. 


\section{A notre Président de thèse :}

\section{Monsieur le Professeur Emmanuel COUDEYRE,}

Nous vous remercions de l'immense honneur que vous nous faites en acceptant la présidence de cette thèse. Veuillez trouver ici l'expression de notre sincère reconnaissance et de notre profond respect.

\section{A notre directeur de thèse :}

\section{Monsieur le Professeur Frédéric DUTHEIL,}

Merci pour votre disponibilité, votre indulgence, ainsi que l'immense aide que nous nous avez apportée et sans laquelle nous n'aurions pas réussi un tel travail. Merci aussi pour votre réassurance par rapport à nos doutes et inquiétudes. Soyez assuré de notre profond respect.

\section{Aux membres du jury de thèse :}

\section{Madame le Docteur Charlotte LANHERS,}

Vous nous faites l'honneur de juger notre travail complétant vos deux très bonnes premières méta-analyses sur la créatine. Nous vous remercions pour l'aide dans l'accomplissement de ce travail.

\section{Monsieur Bruno PEREIRA}

Nous vous sommes reconnaissant d'avoir accepté de faire partie de ce jury de thèse et de nous faire l'honneur de juger notre travail. Soyez assuré de notre profond respect. 
This page intentionally left blank 


\section{Table des matières}

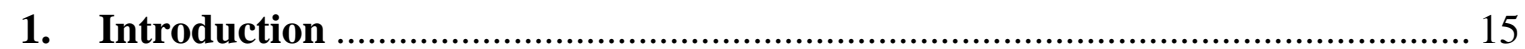

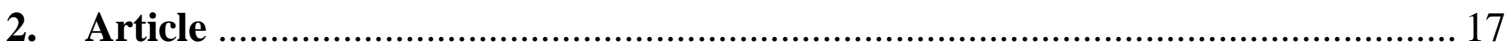

2.1 Title page ............................................................................................................................. 17

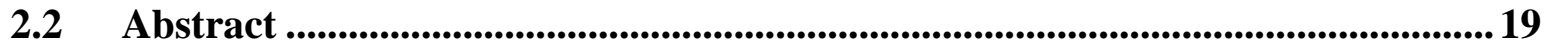

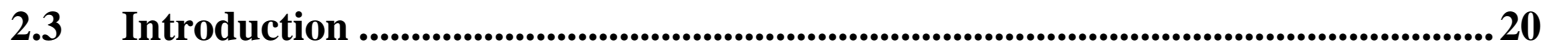

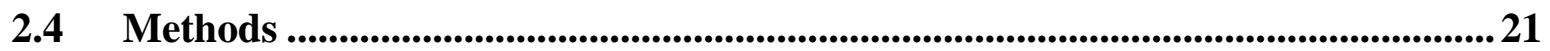

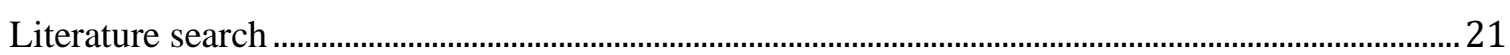

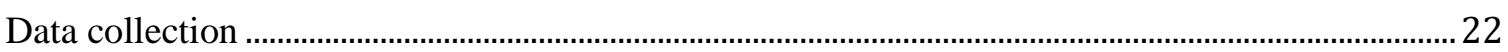

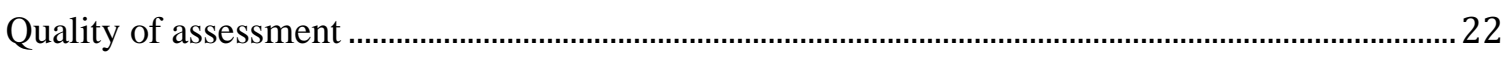

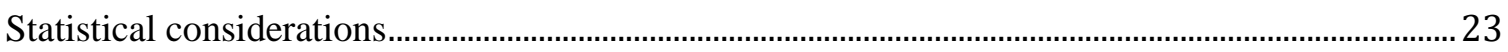

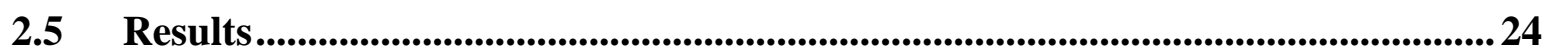

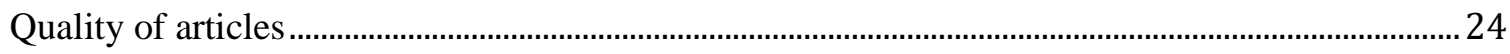

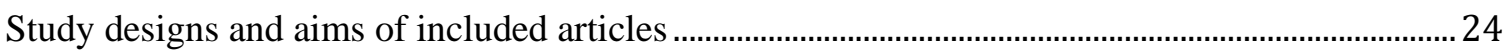

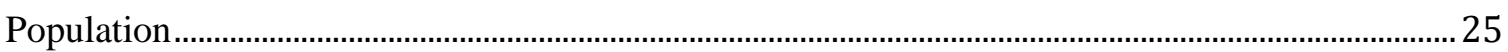

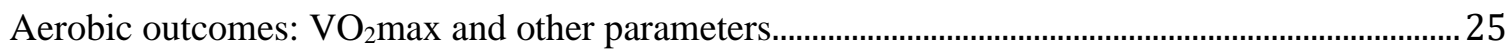

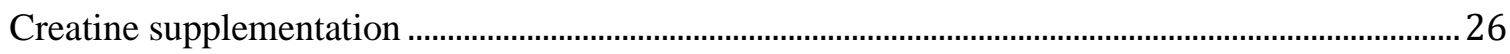

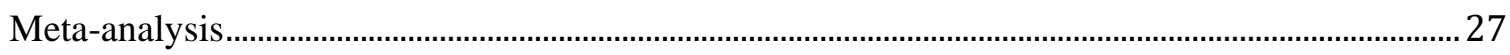

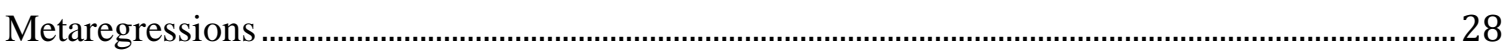

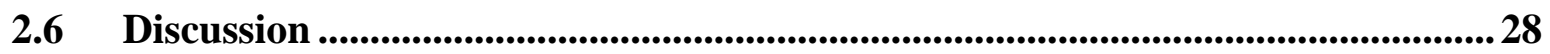

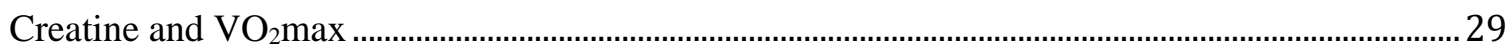

Creatine and secondary outcomes (time to exhaustion, maximal power output and ventilatory

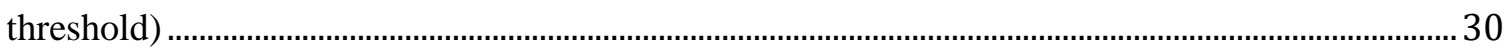

Supplementation protocols and characteristics of individuals.................................................. 31

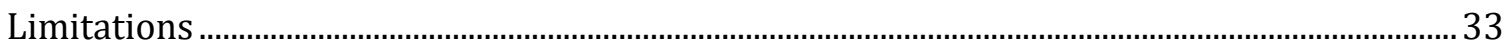

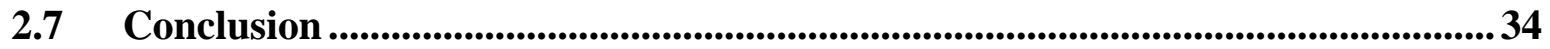

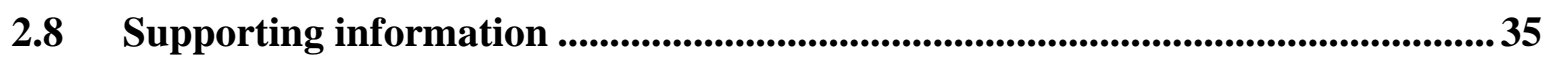

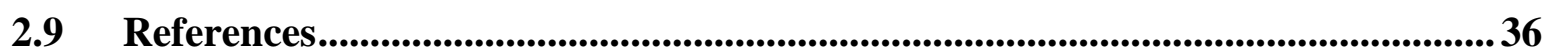

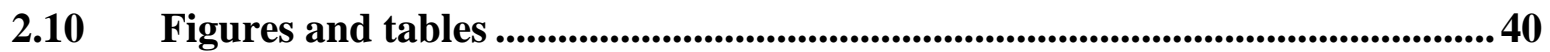

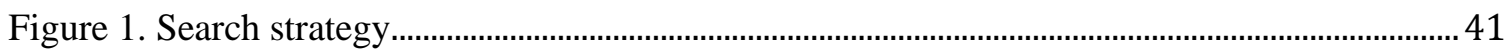

Figure 2. Quality of articles - SIGN checklist........................................................................................ 42

Figure 3. Meta-analyses of changes between groups.............................................................................. 43

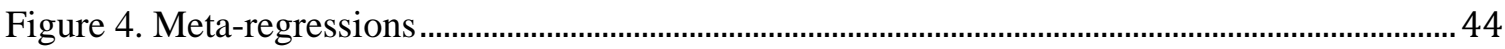


Fig 5. Funnel plots

Table 1. Characteristics of included studies ...................................................................................... 46

S1 Appendix. Details for the search strategy used within each database.............................................48

S2 Appendix. Quality of articles - PEDro scale for RCTs .................................................................... 49

S3 Appendix. Forest plot of aerobic changes in the Cr group compared to the control group within studies included following the supplementation period .50

S4 Appendix. Meta-analyses of aerobic measures at baseline and at T1 between groups, and between $\mathrm{T} 0$ and $\mathrm{T} 1$ within groups for all studies

S5 Appendix. Meta-analyses of aerobic measures at baseline and at T1 between groups, and between $\mathrm{T} 0$ and $\mathrm{T} 1$ within groups after exclusions from meta funnels.

S6 Appendix. Meta-analyses of aerobic measures at baseline and at T1 between groups, and between $\mathrm{T} 0$ and $\mathrm{T} 1$ within groups in young and healthy

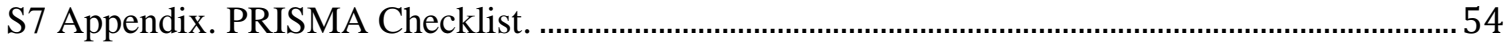

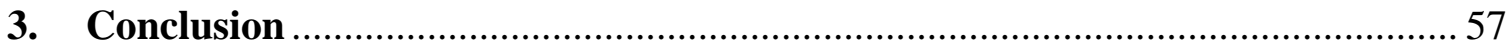


Liste des abréviations

CI95\%: $95 \%$ confidence interval

$\mathrm{Cr}: \mathrm{Cr}$

CrP: Cr Phosphate

CS: CS

ES: Effect Size

SD: Standard Deviation

SEM: Standard Error of the Mean

VO2max: Maximal Oxygen Consumption 


\section{Introduction}

La créatine est un composé organique azoté présent principalement dans les muscles et le système nerveux dont les stocks cellulaires sont entretenus par une alimentation carnée et par la synthèse endogène à partir d'acides aminés tels que la glycine, l'arginine et la méthionine [1]. La créatine est l'un des compléments alimentaires sportifs les plus populaires sur le marché et largement utilisé chez les athlètes professionnels et de loisir avec plus de 400 millions de dollars de ventes annuelles [2]. La popularité de la supplémentation en créatine peut s'expliquer par un marketing intensif sur ses effets bénéfiques dans le sport. Il est bien connu que la supplémentation en créatine améliore la performance lors d'exercices courts à haute intensité tels que les sprints [3] et la force musculaire [4,5] et aurait un intérêt en usage thérapeutique pour promouvoir la santé dans des domaines variés qui sont résumés dans une récente revue de la littérature [6]. Malgré cela, la littérature scientifique actuelle diverge sur les conséquences d'une supplémentation en créatine sur la performance en endurance [7,8]. Le gold-standard pour évaluer les capacités en endurance est la $\mathrm{VO}_{2} \max$ [9]. Celle-ci est définie comme la consommation d'oxygène atteinte à l'intensité maximale de l'exercice ne pouvant être dépassée

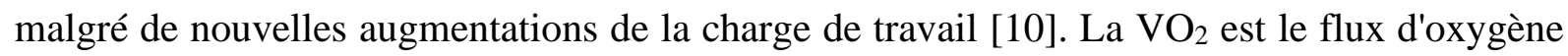
capté par les poumons, transporté dans la circulation sanguine couplé à l'hémoglobine et utilisé pour l'oxydation des substrats énergétiques (glucose et acides gras) dans la chaîne respiratoire des mitochondries aboutissant à la resynthèse de l'ATP [11]. Il a été démontré que la $\mathrm{VO}_{2}$ max est un indice valide mesurant les limites du système cardiorespiratoire [12] et l'un des principaux résultats permettant d'évaluer la capacité cardiorespiratoire et de prédire la performance d'un athlète dans les sports d'endurance $[13,14]$. De plus, l'évaluation de la $\mathrm{VO}_{2}$ max par un test d'effort incrémental semble être l'une des mesures de performance la plus reproductible indépendamment des protocoles utilisés [15]. Certaines études se sont intéressées à évaluer l'effet de la supplémentation en créatine sur la $\mathrm{VO}_{2} \max [16,17]$. L'apport d'énergie 
sous la forme d'ATP à partir de la liaison phosphate riche en énergie de la phosphocréatine se produit pendant les premières secondes d'un effort intense en anaérobie en raison des réserves limitées de phosphocréatine nécessitant une période de récupération de plusieurs minutes avant sa régénération [18]. L'intérêt de la créatine dans des efforts prolongés pourrait être dû à plusieurs mécanismes moins connus tels qu'une facilitation du transport de l'ATP des mitochondries vers le cytosol où l'ATP est consommée pour la contraction musculaire [19], un rôle dans le stockage du glycogène par une augmentation des transporteurs du glucose GLUT4 $[20,21]$ ainsi que des modifications du volume cellulaire par un effet osmotique de la créatine [22]. Outre son rôle dans la régulation et l'homéostasie du métabolisme énergétique, la supplémentation en créatine pourrait améliorer l'activation musculaire [23] et diminuer la consommation d'oxygène par l'organisme à une même intensité d'effort [24,25] pouvant être bénéfique pour la performance en endurance. Outre son utilisation courante dans le sport, la supplémentation en créatine a également été testée chez les personnes âgées et dans certaines conditions pathologiques [26,27]. Malgré ces considérations, les effets de la supplémentation en créatine sur la performance aérobie restent incertains et, à ce jour, aucune méta-analyse n’a spécifiquement étudié son rôle sur la $\mathrm{VO}_{2} \max$.

Ainsi, notre objectif était de mener une revue systématique et une méta-analyse de tous les essais contrôlés randomisés comparant les effets de la supplémentation en créatine par rapport à un placebo sur la $\mathrm{VO}_{2} \max$. Nos objectifs secondaires étaient de déterminer l'influence des caractéristiques de la population, de la supplémentation et de l'entraînement associé sur la $\mathrm{VO}_{2}$ max ainsi que d'évaluer les effets de la supplémentation en créatine sur les mesures aérobies associées à $\mathrm{VO}_{2} \max$ au cours des tests d'effort incrémentaux [28]. 


\section{Article}

\subsection{Title page}

\section{Creatine supplementation and $\mathrm{VO}_{2}$ max:}

\section{A systematic review and meta-analysis}

Damien Gras ${ }^{1}$, Charlotte Lanhers ${ }^{1}$, Reza Bagheri ${ }^{2}$, Ukadike Chris Ugbolue ${ }^{3}$, Emmanuel Coudeyre $^{4}$, Bruno Pereira ${ }^{5}$, Marek Zak ${ }^{6}$, Jean-Baptiste Bouillon ${ }^{7}$, Frédéric Dutheil ${ }^{8}$

${ }^{1}$ Université Clermont Auvergne, University Hospital of Clermont-Ferrand, CHU ClermontFerrand, Physical and Reahbilitation Medicine, F-63000 Clermont-Ferrand, France

${ }^{2}$ University of Isfahan, Exercise Physiology, 8174673441 Isfahan, Iran

${ }^{3}$ University of the West of Scotland, School of Health and Life Sciences, Institute for Clinical Exercise \& Health Science, South Lanarkshire, G72 0LH, Scotland, UK

${ }^{4}$ Université Clermont Auvergne, INRAE, Human Nutrition Unit (UNH), University Hospital of Clermont-Ferrand, CHU Clermont-Ferrand, Physical and Reahbilitation Medicine, F-63000 Clermont-Ferrand, France

${ }^{5}$ University Hospital of Clermont-Ferrand, CHU Clermont-Ferrand, Biostatistics, F-63000 Clermont-Ferrand, France

${ }^{6}$ The Jan Kochanowski University, Faculty of Medicine and Health Sciences, Institute of Physiotherapy, Kielce, Poland

${ }^{7}$ Université Clermont Auvergne, CNRS, LaPSCo, Physiological and Psychosocial Stress, University Hospital of Clermont-Ferrand, CHU Clermont-Ferrand, Emergency Medicine, F63000 Clermont-Ferrand, France 
${ }^{8}$ Université Clermont Auvergne, CNRS, LaPSCo, Physiological and Psychosocial Stress, University Hospital of Clermont-Ferrand, CHU Clermont-Ferrand, Occupational and Environmental Medicine, WittyFit, F-63000 Clermont-Ferrand, France

*Corresponding author: Frédéric Dutheil, Occupational and Environmental Medicine, CHU Clermont-Ferrand, Clermont-Ferrand, France, Tel: +33 6882248 48, Fax: +334732746 49, frederic.dutheil@uca.fr

Competing Interests: The authors have declared that no competing interests exist.

Running title: CS and Aerobic Performance 


\subsection{Abstract}

Background: Despite creatine is well-known to increase performance in acute high intensity exercises, its role in aerobic performance based on $\mathrm{VO}_{2} \max$ is more controversial.

Objectives: To perform a systematic review and meta-analysis on the effects of creatine supplementation on $\mathrm{VO}_{2} \max$.

Method: PubMed, Cochrane, Embase and ScienceDirect were searched for randomized controlled trials (RCTs) reporting $\mathrm{VO}_{2}$ max in both a creatine supplementation and placebo group, after and before supplementation. We computed random-effects meta-analysis on $\mathrm{VO}_{2} \mathrm{max}$ at baseline, within groups following supplementation, on changes in $\mathrm{VO}_{2}$ max between groups, as well after supplementation between groups. Sensitivity analyses were conducted after exclusion of studies outside funnel plots and on young and healthy individuals. Metaregressions were computed to search for influential factors of $\mathrm{VO}_{2} \mathrm{max}$.

Results: We included 19 RCTs for a total of 424 individuals (mean age 30 years old, $82 \%$ men). $\mathrm{VO}_{2}$ max did not differ at baseline between groups (creatine and placebo). Both groups had a training in most studies (80\%). Using changes in $\mathrm{VO}_{2} \max , \mathrm{VO}_{2} \max$ increased in both groups but increased less after creatine than placebo (effect size -0.32 , CI95\% -0.51 to -0.12 ). Comparisons after supplementation confirmed a lower $\mathrm{VO}_{2}$ max in the creatine group compared to the placebo group $(-0.20,-0.39$ to -0.001$)$. Meta-analysis after exclusion from meta-funnel gave similar results, as well as in a subgroup of young and healthy participants. Metaregressions on characteristics of supplementation, physical training, or sociodemographic were not significant.

Conclusion: Creatine supplementation has negative effect on $\mathrm{VO}_{2} \mathrm{max}$, regardless of the characteristics of training, supplementation, or population characteristics.

Keywords: dietary supplement, endurance, cardiorespiratory fitness, $\mathrm{VO}_{2}$ peak, ventilatory threshold. 


\subsection{Introduction}

Creatine $(\mathrm{Cr})$ is one of the most popular sport dietary supplement on the market widely used among recreational and professional athletes, with more than $\$ 400$ million in annual sales [1]. The popularity of Cr supplementation (CS) can be explained by an intensive marketing about its ergogenic effects particularly in sport performance. Its largely admitted that CS improves performance in acute and high intensity exercises such as sprints [2] and muscle strength $[3,4]$ and have health and potential therapeutic benefits [5]. Despite this, the current scientific literature diverges on its potential effects on endurance performance [6,7]. The gold standard to assess endurance capacities is $\mathrm{VO}_{2} \max [8] . \mathrm{VO}_{2} \max$ is defined as the oxygen uptake attained during maximal exercise intensity that could not be increased despite further increases in exercise workload [9]. $\mathrm{VO}_{2}$ is the oxygen flow taken by the lungs, transported through the blood circulation coupled with hemoglobin, and used for the oxidation of energy substrates (glucose and fatty acids) in the respiratory chain of mitochondria resulting in ATP resynthesis [10]. It was demonstrated that $\mathrm{VO}_{2} \max$ is a valid index measuring the limits of the cardiorespiratory system [11] and one of the main outcome that can predict performance in endurance sports $[12,13]$. Moreover, the assessment of $\mathrm{VO}_{2} \max$ through an incremental exercise test seems to be one of the most reproductible measurement independently of protocols used [14]. Some studies had investigated the effect of $\mathrm{CS}$ on $\mathrm{VO}_{2} \max [15,16]$. The ATP energy supply by the energyrich phosphate bond of phosphocreatine $(\mathrm{CrP})$ occurs during the first seconds of an high intensity exercise in anaerobic condition due to the limited $\mathrm{CrP}$ stores requiring a recovery period of several minutes before its regeneration [17]. In prolonged efforts, $\mathrm{Cr}$ could interact with aerobic metabolism through several lesser known mechanisms with a $\mathrm{Cr}$ phosphate shuttle facilitating the ATP transport from the mitochondria to the cytosol within the cell needing ATP for muscle contraction [18] and a role in increasing glycogen storage with an increase in GLUT4 transporters $[19,20]$ as well as changes in cell volume with osmotic effect of $\mathrm{Cr}$ [21]. In addition 
to its role in the regulation and homeostasis of energy metabolism, CS could improve muscle activation [22] and $\mathrm{VO}_{2}$ kinetics at same workloads [23,24] which may be beneficial for endurance performance. Besides its common use in sports, CS has also been tested in elderly and in certain pathological conditions [25,26]. Despite these considerations, the effects of CS on aerobic performance remain uncertain and, to date, no meta-analysis has specifically focused on its effects in changes in $\mathrm{VO}_{2}$ max levels.

Thus, we aimed to conduct a systematic review and meta-analysis of all randomized controlled trials (RCTs) comparing the effects of CS versus placebo on $\mathrm{VO}_{2}$ max. Secondary aims were to determine the influence of population characteristics, supplementation, and physical training associated on $\mathrm{VO}_{2}$ max levels as also as to assess the effects of $\mathrm{CS}$ on aerobic measures associated with $\mathrm{VO}_{2}$ max during incremental exercise tests [27].

\subsection{Methods}

\section{Literature search}

We search for all RCTs with CS versus placebo, with a measure of $\mathrm{VO}_{2}$ max before and after supplementation. PubMed, The Cochrane Central Register of Controlled Trials (CENTRAL), Excerpta Medica Database (EMBASE), and ScienceDirect were searched until March $1^{\text {st }} 2020$ using the keywords "VO${ }_{2}$ max" AND "creatine supplementation" (see detailed search strategy in S1 Appendix). The search was not limited to specific years. No language restrictions were applied. Reference lists of all publications meeting the inclusion criteria were manually searched to identify any further studies not found through electronic searching. Two authors (DG and CL) conducted all literature searches, separately reviewed and collated the abstracts, and based on the selection criteria decided the suitability of the articles for inclusion. A third author FD) was asked to review the article when consensus on suitability was not met. Then, 
all authors reviewed the eligible articles (Figure 1). We followed the PRISMA guidelines (S7 Appendix ).

\section{Data collection}

The data collected included first author's name, publication year, study design, periods of studies, aims and outcomes of included articles, sample size, characteristics of individuals (age, gender, physical activity, health status), supplementation protocol (type of $\mathrm{Cr}$, total time of supplementation, total dose), physical training during supplementation period, $\mathrm{VO}_{2} \max$ (values in each unit, and measurement method), and performance associated with the incremental test (ventilatory threshold, time to exhaustion, maximal power output).

\section{Outcomes}

The main outcome for our meta-analysis was $\mathrm{VO}_{2} \max$. Our secondary outcomes were ventilatory threshold, time to exhaustion and maximal power output from incremental exercise tests if measures were available.

\section{Quality of assessment}

The Scottish Intercollegiate Guidelines Network (SIGN) checklist for RCTs was used to assess the quality of reporting (Figure 2) [28]. Through 11 items, the SIGN checklist evaluates internal validity and study quality. Additionally, the PEDro scale was assessed for each study (S2 Appendix) [29]. Methodological quality of articles was evaluated by two independent reviewers. 


\section{Statistical considerations}

Data were analysed using Stata (v16, Texas, USA). When not available, standard deviation (SD) were calculated by multiplying the Standard Error of the Mean (SEM) by the square root of the sample size [30], or estimated from interval quartiles or minimum and maximum intervals [31]. The main meta-analysis compared changes in $\mathrm{VO}_{2}$ max between groups (CS versus placebo). Changes were calculated using the method from Borenstein et al. [32]. Results were expressed as effect size (ES) [33]. A decreased ES denoted a lower improvement in $\mathrm{VO}_{2} \mathrm{max}$ in the Cr group compared to the placebo group. A scale for ES has been suggested with -0.2 reflecting a small effect, -0.5 a moderate effect, and -0.8 a large effect [34]. In order to verify the strength of our results, we also computed random-effects meta-analysis on $\mathrm{VO}_{2} \max 1$ ) at baseline between groups (CS versus placebo) to verify that groups were comparable, 2) within groups after supplementation, 3) as well after supplementation between groups. Each metaanalysis was stratified by type of exercise (running, cycling or rowing), and by units of measure (L/min or $\mathrm{mL} / \mathrm{kg} / \mathrm{min})$. Finally, we also conducted meta-analyses on ventilatory threshold, maximal power output and time to exhaustion on the incremental exercise tests. For all aforementioned meta-analyses, sensitivity analyses were conducted after exclusion of studies outside funnel plots and on young and healthy individuals. Heterogeneity between studies was also evaluated using $\mathrm{I}^{2}$ statistic, ranging from 0 (no heterogeneity) to $100 \%$ (high heterogeneity). Metaregressions were computed to search for putative influential factors of $\mathrm{VO}_{2} \mathrm{max}$, such as characteristics of population (age, gender, training and health), characteristics of supplementation (loading dose, total duration of supplementation and total dose) and characteristics of training during supplementation (none, aerobic or HIIT). Results were expressed as regression coefficients and 95\%CI. P values less than 0.05 were considered statistically significant. 


\subsection{Results}

An initial search produced a possible 4985 articles. Removal of duplicates and use of the selection criteria reduced the number of articles reporting $\mathrm{VO}_{2} \mathrm{max}$ assessment at baseline and following CS or placebo to nineteen articles, among them one study reported two independent gender groups [35]. All articles were written in English (Figure 1).

\section{Quality of articles}

Risk of bias in included studies was mostly low (Figure 2 and S2 Appendix). However, most studies did not describe the randomization method. Some studies matched subjects based on the baseline measurements. Two studies used a single-blind design $[25,36]$, but all of the participants were blind about supplementation. Three studies declared to have more than twenty percent of dropped out [16,36,37]. All studies mentioned ethical approval.

\section{Study designs and aims of included articles}

All studies were double blind randomized placebo-controlled trials. Only one study had a crossover design [37]. All the studies were monocentric. Five studies were conducted in Europe (Germany [37], Netherlands [38,39], Poland [40] and Sweden [15]), one in Brazil [26,41], eight in North America (Canada [42] and USA [16,24,25,35,43,44,45]), and four in Australia $[23,36,46,47]$. The duration between baseline and measures after supplementation ranged from 4 [46] to 180 days [26]. The nineteen included studies aimed to evaluate the effect of CS on performance or quality of life in elderly and patients with heart failure $[25,26,37,45]$, among which nine studies aimed specifically at assessing aerobic performance 
$[15,16,23,24,35,36,42,43,47]$. If seventeen studies were on heathy individuals, two studies recruited patients with heart failure [26,37] (Table 1).

\section{Population}

Sample size ranged from 10 [40] to 46 [39], for a total of 424 participants (216 in the CS group and 208 individuals in the placebo group).

Gender was reported in all studies. Mean proportion of males was $81.7 \%$, with 160 males and 56 females in the CS group versus 155 males and 53 females in the placebo group. Eleven studies included only men $[15,23,24,26,38,39,41,43,45,46]$, three only women $[25,42,44]$.

Age was reported as mean values in all studies except for three studies that reported age in min-max interval [15,36,41]. Mean age was 29.7 years old, ranging from 20.5 [46] to 68 [25] years old. Most studies (79\%) had participants aged between 18 and 40 years old.

Physical activity at baseline was reported in all studies. We classified individuals as competitive or highly trained athletes $(15.6 \%)[15,40,41,47]$, recreationally trained $(54.2 \%)$ $[16,23,24,35,36,42,43,44,45,46]$, and sedentary or have low daily physical activity $(30.2 \%)$ $[25,26,37,38,39]$.

Additional outcomes were seldomly reported such as echocardiographic measures [23,37] or cellular changes using muscular biopsy [24,36,38,39,44] (Table 1).

\section{Aerobic outcomes: $\mathrm{VO}_{2} \max$ and other parameters}

Measurements of maximal oxygen consumption were reported in $\mathrm{VO}_{2} \mathrm{max}$ $[15,23,24,35,37,38,41,45]$ or $\mathrm{VO}_{2}$ peak $[16,25,26,36,39,40,42,43,44,46,47]$. We chose to use $\mathrm{VO}_{2} \max$ as a generalization in this article. Nine studies measures $\mathrm{VO}_{2}$ in $\mathrm{L} / \mathrm{min}$ $[16,23,24,38,39,42,43,46,47]$ and eleven in $\mathrm{mL} / \mathrm{min} / \mathrm{kg}[15,25,26,35,36,37,40,41,42,44,45]-$ 
among them one study reported both $\mathrm{L} / \mathrm{min}$ and $\mathrm{mL} / \mathrm{kg} / \mathrm{min}$ [42]. Most studies measured $\mathrm{VO}_{2}$ with gas exchange analysis during incremental exercise tests such as bicycle ergometer test $[16,23,24,25,26,36,38,39,42,43,44,46]$, treadmill test $[15,35,37,40,45]$ or rowing ergometer test [47]. The incremental tests were as close as possible to the training habitus of participants. $\mathrm{VO}_{2} \max$ was also extrapolated from sub-maximal measures of $\mathrm{VO}_{2}$ in two studies $[45,48]$ and estimated through a 12-minute Cooper test in one study [41]. Ten studies also assessed ventilatory threshold, using the V-slope method [49] in six studies [16,26,37,39,42,43] - i.e. the point where $\mathrm{VCO}_{2}$ production increases more than $\mathrm{VO}_{2}$ consumption -, the "Wasserman" method [50] in three studies $[25,35,44]$ - i.e. the point where $\mathrm{VE} / \mathrm{VO}_{2}$ increases without a concomitant increase in $\mathrm{VE} / \mathrm{VCO}_{2}-$, and without further information in one study [40]. Six studies reported time to exhaustion $[23,35,43,44]$ or maximal power output $[25,38,39]$ at the incremental tests (Table 1 and S3 Appendix).

\section{Creatine supplementation}

$\mathrm{Cr}$ monohydrate was used in $74 \%$ of studies, $\mathrm{Cr}$ citrate in two studies $[35,43], \mathrm{Cr}$ malate in one study [40], and not reported in two studies [26,37]. A loading dose was used in twelve studies i.e. a dose $\geq 20 \mathrm{~g} / \mathrm{day}$ or $0.3 \mathrm{~g} / \mathrm{kg}$ which had shown the greatest effectiveness for increasing muscle total $\mathrm{Cr}$ content with minimal $\mathrm{Cr}$ losses through renal excretion [51], splitted in two [42], three $[25,41,45]$ or four $[16,23,35,36,37,38,44,47]$ intakes per day, during 4 to 7 days for all studies except one that used a loading dose for a prolonged period [37]. A maintenance dose ranging from 2 [23] to $10 \mathrm{~g} /$ day [23] was used in six studies, once daily except for one study [23]. Seven studies did not used a loading dose and supplemented only with a low dose of $\mathrm{Cr}$ $[15,24,26,39,40,43,46]$. In total, the CS was $285 \mathrm{~g}$ in average, ranging from $42 \mathrm{~g}$ [46] to $912 \mathrm{~g}$ [39], over a period of 42 days, ranging from four days [46] to six months [39] (Table 1). 


\section{Training during supplementation}

In all studies, all participants performed the same physical training and differed only by the supplementation (Cr or placebo). A standardized training program was proposed in six studies: high-intensity interval training (HIIT) [42,43], resistance [45], aerobic [36], or mixed training $[39,41]$. Nine studies maintained the usual physical activity of participants i.e. running [15], cycling [24] rowing [47], team sports [23], judo [40] or other recreational activities $[16,35,44,46]$. Four studies included sedentary participants without exercise intervention $[25,26,37,38]$. We classified exercise training as "aerobic" $(68.9 \%)$, "anaerobic" $(11.8 \%)$, and “none" (19.3\%) (Table 1).

\section{Meta-analysis}

There were no differences in any outcomes at baseline between group $\mathrm{Cr}$ and placebo groups (S4 Appendix). Using changes from baseline to after the supplementation, $\mathrm{VO}_{2}$ max increased less in the Cr group compared to the control group ( $\mathrm{ES}=-0.30, \mathrm{CI} 95 \%-0.50$ to $-0.11, \mathrm{p}=0.003)$. Stratification showed a lower increase in the $\mathrm{Cr}$ group for $\mathrm{VO}_{2} \max$ in $\mathrm{L} / \mathrm{min}(-0.39,-0.67$ to 0.12, $\mathrm{p}=0.005)$, and for cycling $(-0.33,-0.58$ to $-0.09, \mathrm{p}=0.007)$. Other aerobic outcomes (ventilatory threshold, time to exhaustion, maximal power output) did not differ between groups (Figure 3).

\section{Sensitivity analyses}

Meta-analyses comparing $\mathrm{VO}_{2}$ max after supplementation between groups demonstrated similar results than meta-analyses on changes i.e. a significant lower $\mathrm{VO}_{2} \max$ in the $\mathrm{Cr}$ compared with the placebo group $(-0.2,-0.39$ to $-0.001, \mathrm{p}=0.049)$, as well as for $\mathrm{VO}_{2}$ max expressed in $\mathrm{L} / \mathrm{min}$ $(-0.32,-0.59$ to $-0.04, p=0.022)$, and a tendency for cycling $(-0.22,-0.46$ to $0.02, \mathrm{p}=0.074)$ (S4 Appendix). We also computed meta-analyses on $\mathrm{VO}_{2}$ max changes within groups: $\mathrm{VO}_{2}$ max 
increased in the placebo group $(0.35,0.15$ to $0.54, \mathrm{p}=0.001)$, with only a tendency within the the Cr group $(0.18,-0.01$ to $0.37, p=0.060)$. Despite a very limited number of studies $(n=3)$ for this parameter, maximal power output increased in the $\operatorname{Cr}$ group $(0.45,0.03$ to $0.88, \mathrm{p}=0.038)$. All aforementioned meta-analysis were repeated after exclusion of studies not evenly distributed around the base of the metafunnel, and demonstrated similar findings (S5 Appendix). Lastly, we also repeated all meta-analyses in the subgroup of young and healthy participants and results were similar i.e. a lower $\mathrm{VO}_{2} \max$ increase in the creating compared to the placebo group using changes between groups $(-0.26,-0.49$ to $-0.02, \mathrm{p}=0.031)$, a lower $\mathrm{VO}_{2}$ max after supplementation in the creating compared to the placebo group $(-0.26,-0.49$ to 0.02, $\mathrm{p}=0.031)$, an increase in $\mathrm{VO}_{2} \max$ within the placebo group $(0.25,0.02$ to $0.48, \mathrm{p}=0.035)$ and not within the $\mathrm{Cr}$ group $(0.10,-0.13$ to $0.32, \mathrm{p}=0.41)$. Using changes between groups, ventilatory threshold increased in the $\mathrm{Cr}$ compared to the control group $(0.66,0.23$ to 1.1 , $\mathrm{p}=0.003)$ (Figure 3 and S6 Appendix).

\section{Metaregressions}

The meta-regressions failed to show any influencing variables on the $\mathrm{VO}_{2}$ max i.e. the putative influence of individuals, supplementation, or training characteristics. The limited number of patients with heart failure precluded analyses on the influence of health status on $\mathrm{VO}_{2} \mathrm{max}$ (Figure 4).

\subsection{Discussion}

The main findings were that $\mathrm{CS}$ is detrimental to $\mathrm{VO}_{2} \mathrm{max}$, especially for cycling. If CS was also not beneficial on the maximal aerobic parameters associated with $\mathrm{VO}_{2}$ max, ventilatory threshold seemed to be improved. Results were independent of sociodemographic or supplementation characteristics. 


\section{Creatine and $\mathrm{VO}_{2} \mathrm{max}$}

$\mathrm{Cr}$ is well-known for ergogenic effects in acute high intensity exercises. However, current results of our meta-analysis led to adverse effects of CS on endurance capacity assessed with $\mathrm{VO}_{2}$ max which increased in the placebo group but not in the Cr group. $\mathrm{VO}_{2}$ max limiting factors are shared between central factors for $\sim 70 \%$ and peripheral factors for $\sim 30 \%$ [52]. Thus, $\mathrm{O}_{2}$ delivery and particularly maximal cardiac output are known as primary limiting factors for $\mathrm{VO}_{2}$ max in exercising humans [10]. $\mathrm{Cr}$ is known to induce water retention in tissues increasing their $\mathrm{Cr}$ content after supplementation such as skeletal muscle [53] and potentially cardiomyocytes [54]. However, knowledge of the effects of cardiomyocytes swelling on contractile function and consequences on blood flow during exercise are lacking and still questionable. Several methods exist to determine maximal cardiac output during exercise [55] but none of them was applied among included studies. Echocardiography found no change in ejection fraction and left ventricular diameters after CS at rest [23,37] and during maximal exercise [56]. In addition to the cardiac function, $\mathrm{O}_{2}$ delivery to working muscles also depends on arterial oxygen content. Thus, hemoglobin and hematocrit levels are not modified at rest following CS [7,24,57]. However, it was observed that CS can alter plasma volume during exercise [24] but negative consequences on muscles oxygen supply and $\mathrm{VO}_{2}$ max levels were not demonstrated. Changes in oxygen saturation during exercise after CS was not reported among studies. Finally, the $\mathrm{Cr}$ effect on central limiting factors of $\mathrm{VO}_{2}$ max does not appear to be essential. This can be explained by the fact that CS rather acts at the peripheral muscle level and as $\mathrm{Cr}$ is well-known to improve anaerobic performances through the hypertrophy and the higher recruitment in fast-twitch muscle fibers [53], changes in skeletal muscle energy metabolism could have explain our negative findings on $\mathrm{VO}_{2} \mathrm{max}$. This hypothesis is supported by the lack of improvement in muscle oxidative capacity following CS [38,58]. Some studies reported improvement in muscular glycogen content following CS when associated with 
carbohydrates intake and physical training but this effect on energy storage can help to maintain prolonged effort but not affect $\mathrm{VO}_{2}$ max level. $\mathrm{CS}$ has negative effect on $\mathrm{VO}_{2}$ max which should be considered for its application in cardiovascular disease involving a decrease in $\mathrm{VO}_{2} \mathrm{max}$, in elderly patients despite potential effects to prevent sarcopenia or bone loss [5], and in endurance athletes for which $\mathrm{VO}_{2} \max$ is a determining factor of performance more than the ability to achieve a longer distance at submaximal intensity. At this intensity, the increase in the ventilatory threshold found in young subjects could be an asset for performance.

\section{Creatine and secondary outcomes (time to exhaustion, maximal power output and}

\section{ventilatory threshold)}

The ventilatory threshold refers to the point during exercise at which ventilation starts to increase at a faster rate than $\mathrm{VO}_{2}$ related to onset lactate accumulation [50]. The ventilatory threshold occurs at a higher percentage of $\mathrm{VO}_{2} \max$ in well-trained endurance athletes [59] and can predict endurance performance as well as in sedentary or recreationally trained [60] and endurance athletes [61]. The increase in the ventilatory threshold found after CS in young and healthy is in accordance with greater exercise efficiency at submaximal workloads resulting in a decrease of $\mathrm{O}_{2}$ consumption $[16,23,24]$ reliable to a reduction in the work performed by the cardiovascular system at these intensities [16]. Hypothesis are that $\mathrm{CrP}$ hydrolysis consumes hydrogen ions and might contribute to the buffering of intracellular acidosis when ATP resynthesis occurs from $\mathrm{CrP}$ stores [62]. Moreover, an increase in muscle $\mathrm{CrP}$ levels due to $\mathrm{CS}$ could delayed the decrease in the ATP/ADP ratio needed to stimulate mitochondrial respiration and $\mathrm{VO}_{2}$ [49]. Also, an increase in mechanical efficiency could also participate [16,22]. Improvement in ventilatory threshold is given for young subjects and why this result was not observed in the elderly population even without patients with heart failure remains unclear. 
No statistical change occurred in maximal power output and exercise time to exhaustion following CS. While CS increased peak power during sprints [38], no improvement in maximal aerobic power was found among limited number of studies [25,38,39]. As maximal power output for cycling, we could not conduct analysis on maximal aerobic speed or velocity at $\mathrm{VO}_{2} \max \left(\mathrm{vVO}_{2} \max \right)$ because this measurement was not provided by studies [63]. Here, we used time to exhaustion which refers to the time measured from the start of the incremental treadmill test until $\mathrm{VO}_{2}$ max was reach with the same protocol at baseline and $\mathrm{T} 1$ within studies. A higher time to exhaustion means a better performance on the aerobic test. This measurement has a certain limitation because it depends even more on the protocol of the incremental test. Besides these considerations and the greater number of studies reporting time to exhaustion than maximal power output we found no significant change in this parameter after CS compared to placebo. As describe above, the lack of improvement in muscle oxidative capacity after CS could explain these results on maximal aerobic power and time to exhaustion which mainly depends on the work of oxidative muscle fibers [63]. Finally, CS seems to not increase maximal aerobic performances more than training alone.

\section{Supplementation protocols and characteristics of individuals}

Monohydrate form of $\mathrm{Cr}$ was mostly used without influence on $\mathrm{VO}_{2} \mathrm{max}$ of one or other forms of $\mathrm{Cr}$. Whey proteins added to $\mathrm{Cr}$ seems to have no additional benefits on $\mathrm{VO}_{2}$ max in older adults [45]. A Cr loading dose is admitted at a dosage about $0.3 \mathrm{~g} / \mathrm{kg} / \mathrm{day}$ which had shown the greatest effectiveness to increase muscle total $\mathrm{Cr}$ content with minimal $\mathrm{Cr}$ losses through renal excretion [51]. A meta-analysis not presented in this paper found less changes in $\mathrm{VO}_{2}$ max levels immediately after $\mathrm{Cr}$ loading compared to placebo. A maintenance dose of $0.06 \mathrm{~g} / \mathrm{kg}$ is necessary to raise plasma $\mathrm{Cr}$ concentration required for the uptake of $\mathrm{Cr}$ by skeletal muscle [47]. Among studies included, only three employed lower daily $\mathrm{Cr}$ doses [24,38,41] but 
muscular biopsies for two of them also found significant increase in total muscle $\mathrm{Cr}$ content. Conversely, two studies with higher $\mathrm{Cr}$ doses $[36,44]$ did not found significant increase in muscle Cr content. These results could be explained by different responder profiles. Indeed, better responder profiles have lower initial Cr muscle levels [64] and/or higher proportion of fast-twitch muscle fibers [53]. The limited number of muscular biopsies in studies did not allow to assess changes in aerobic performance based on the response profile. Heterogeneity was also found in the supplementation duration which varied from 4 days to 6 months but did not appear to be a determining factor for $\mathrm{VO}_{2}$ max changes.

CS has been most extensively studied in young and trained males. Few studies had reported sexbased differences for strength gains with greater improvement in men $[64,65]$. Reasons are lower proportion of lean mass, higher baseline $\mathrm{Cr}$ muscle content [65] and lower training adaptations in women [66]. Only one study assessed changes in $\mathrm{VO}_{2}$ max levels with gender comparisons and did not found difference in response to CS on this outcome and time to exhaustion [35].

In an elderly population, despite improvement in muscle strength [67] and in ability to perform functional living tasks, CS did not improve endurance capacity even when combined with resistance or aerobic training $[25,39,45]$.

Patients with heart failure appeared to increase muscle strength as much as healthy $[37,56]$ but not $\mathrm{VO}_{2} \mathrm{max}$ and functional capacity such as walking distance [26,37] or quality of life [37]. Furthermore, no major change in ejection fraction at rest or during exercise occurs $[37,56]$.

CS increases more muscle mass and muscle strength when combined with resistance training by acting both rather on fast-twitch muscle fibers [68]. Endurance performance depends more of the proportion and the oxidative capacity of low-twitch muscle fibers [53] that could explain the less evident results of CS on aerobic measurements. While HIIT partly involves anaerobic capacities and shows interesting results on $\mathrm{VO}_{2} \max$ [69], no influence of this type of training was found on $\mathrm{VO}_{2} \max$ when associated with CS. CS limited more $\mathrm{VO}_{2}$ max on cycling than running or rowing that could be explain by the greatest number of subjects performing cycling. 
It is known that CS causes body mass gain [70] but the adverse effect of $\mathrm{Cr}$ on $\mathrm{VO}_{2}$ max does not appear to be explain with changes in body mass in a meta-analysis we have not presented here. Also, only three studies reported body mass index without significant increase after CS $[38,40,47]$. Furthermore, if body mass gain had influenced $\mathrm{VO}_{2}$ max levels, its measurements in $\mathrm{mL} / \mathrm{kg} / \mathrm{min}$ should have been lower than the measurements in $\mathrm{L} / \mathrm{min}$ which was not observed.

\section{Limitations}

This is the first meta-analysis that has focused on the effect of CS on $\mathrm{VO}_{2}$ max levels. Many studies did not report all the results to be include in the meta-analysis. For instance, studies reported baseline measurement without measurement after supplementation for $\mathrm{VO}_{2} \mathrm{max}$ or without its change expression [16,71] or did not expressed dispersion of its measurement [72]. Our study has some limitations inherited of all meta-analyses [73] but the use of rigorous inclusion criteria i.e. double blind randomized controlled trials limited the publication bias. A bias of reporting due to the scarcity of publications with negative findings is common to all systematic review and meta-analyses but could reinforce our main findings. A publication bias was also assessed according to funnel plots and sensitivity analyses gave similar results on the main outcome. Not all studies employed measurements of $\mathrm{VO}_{2}$ with gas exchange analysis during incremental exercise tests which could have led to a measurement bias. In fact, the rigorous determination of $\mathrm{VO}_{2}$ max depends on the met of different criterion (plateau in oxygen consumption, respiratory exchange ratio $>1,1$, heart rate greater than age-predicted maximal heart rate, blood lactates > 6-8 mmol or physical exhaustion [74]). In our meta-analysis, $\mathrm{VO}_{2} \max$ was report through rigorous determination by three studies $[23,24,35]$. Four studies $[16,25,42,43]$ assessed $\mathrm{VO}_{2}$ peak as the highest average $\mathrm{VO}_{2}$ obtained for any period of time between 15-second [43] and 1-minute [25] without specifying if a $\mathrm{VO}_{2}$ plateau was obtained. Ten studies did not provide additional information for the determination of the maximum 
oxygen uptake and mentioned $\mathrm{VO}_{2} \max [15,38]$ or $\mathrm{VO}_{2}$ peak $[26,36,37,39,40,44,46,47]$ without precision and two studies had estimated $\mathrm{VO}_{2} \max [41,45]$. The fact that most studies assessed $\mathrm{VO}_{2}$ peak instead of $\mathrm{VO}_{2}$ max can questioned the maximality of the incremental tests and the measures reproducibility at baseline and following supplementation within these studies [27]. To assess the impact of training associated with the CS, we used a clearly unperfect classification of the type of training performed during the supplementation and the physical level of participants. Unfortunately, this last classification was not possible mainly because of the variations of $\mathrm{VO}_{2}$ max with gender.

Most of the performance variables included in this meta-analysis were measured in a laboratory setting and field-based endurance performance must be assessed.

\subsection{Conclusion}

Creatine supplementation has negative effect on $\mathrm{VO}_{2} \max$, regardless of the supplementation protocols, physical training and population characteristics. Considering that creatine is the most widely used dietary supplement in sport, a particular attention towards its used should be paid for endurance athletes. 


\subsection{Supporting information}

S1 Appendix. Details for the search strategy used within each database

S2 Appendix. PEDro scale

S3 Appendix. Meta-analyses of aerobic measures at baseline and at T1 between groups, and between $\mathrm{T} 0$ and $\mathrm{T} 1$ within groups for all studies

S4 Appendix. Meta-analyses of aerobic measures at baseline and at $\mathrm{T} 1$ between groups, and between $\mathrm{T} 0$ and $\mathrm{T} 1$ within groups after exclusions from meta-funnels.

S5 Appendix. Meta-analyses of aerobic measures at baseline and at T1 between groups, and between T0 and T1 within groups in young and healthy.

S6 Appendix. PRISMA Checklist

\section{Acknowledgements}

The authors received no specific funding for this work.

\section{Competing Interests}

No conflicting relationship exists for any author.

\section{Author contributions}

Conceived and designed the study: FD. Conducted the systematic literature search: DG, CL. Final approval of eligible articles: all authors. Analyzed the data: DG, FD. Wrote the first draft of the article: DG, FD. Critical revision of the article: all authors. Integrity of the data analysis: DG, FD.

\section{Data availability statement}

All relevant data are within the paper. 


\subsection{References}

1. Momaya A, Fawal M, Estes R. Performance-Enhancing Substances in Sports: A Review of the Literature. Sports Med 2015; 45:517-531.

2. Dawson B, Cutler M, Moody A et al. Effects of oral creatine loading on single and repeated maximal short sprints. Aust J Sci Med Sport 1995; 27:56-61.

3. Lanhers C, Pereira B, Naughton G et al. Creatine Supplementation and Lower Limb Strength Performance: A Systematic Review and Meta-Analyses. Sports Med Auckl NZ 2015; 45:1285-1294.

4. Lanhers C, Pereira B, Naughton G et al. Creatine Supplementation and Upper Limb Strength Performance: A Systematic Review and Meta-Analysis. Sports Med Auckl NZ 2017; 47:163-173.

5. Kreider RB, Stout JR. Creatine in Health and Disease. Nutrients 2021; 13.

6. Engelhardt M, Neumann G, Berbalk A et al. Creatine supplementation in endurance sports. Med Sci Sports Exerc 1998; 30:1123-1129.

7. Preen D, Dawson B, Goodman C et al. Effect of creatine loading on long-term sprint exercise performance and metabolism: Med Sci Sports Exerc 2001;814-821.

8. VO2 Max - an overview | ScienceDirect Topics 2021.

9. Hill AV, Lupton H. Muscular Exercise, Lactic Acid, and the Supply and Utilization of Oxygen. QJM Int J Med 1923; os-16:135-171.

10. Bassett DR. Limiting factors for maximum oxygen uptake and determinants of endurance performance: Med Sci Sports Exerc 2000;70.

11. Hawkins MN, Raven PB, Snell PG et al. Maximal oxygen uptake as a parametric measure of cardiorespiratory capacity. Med Sci Sports Exerc 2007; 39:103-107.

12. Lanferdini FJ, Silva ES, Machado E et al. Physiological Predictors of Maximal Incremental Running Performance. Front Physiol 2020; 11:979.

13. Kipp S, Kram R, Hoogkamer W. Extrapolating Metabolic Savings in Running: Implications for Performance Predictions. Front Physiol 2019; 10:79.

14. Chidnok W, DiMenna FJ, Bailey SJ et al. VO2max is not alterated by self-pacing during incremental exercise. Eur J Appl Physiol 2013; 113:529-539.

15. Balsom PD, Harridge SD, Söderlund K et al. Creatine supplementation per se does not enhance endurance exercise performance. Acta Physiol Scand 1993; 149:521-523.

16. Nelson AG, Day R, Glickman-Weiss EL et al. Creatine supplementation alters the response to a graded cycle ergometer test. Eur J Appl Physiol 2000; 83:89-94.

17. Gastin PB. Energy System Interaction and Relative Contribution During Maximal Exercise. Sports Med 2001; 31:725-741.

18. Wallimann T, Tokarska-Schlattner M, Schlattner U. The creatine kinase system and pleiotropic effects of creatine. Amino Acids 2011; 40:1271-1296.

19. Ju J-S, Smith JL, Oppelt PJ et al. Creatine feeding increases GLUT4 expression in rat skeletal muscle. Am J Physiol Endocrinol Metab 2005; 288:E347-352.

20. Eijnde BO 't, Ursø B, Richter EA et al. Effect of Oral Creatine Supplementation on Human Muscle GLUT4 Protein Content After Immobilization. Diabetes 2001; 50:18-23.

21. Loon LJCV, Murphy R, Oosterlaar AM et al. Creatine supplementation increases glycogen storage but not GLUT-4 expression in human skeletal muscle. Clin Sci 2004; 106:99-106.

22. Da Silva Azevedo AP, Michelone Acquesta F, Lancha Jr. AH et al. Creatine supplementation can improve impact control in high-intensity interval training. Nutrition 2019; 61:99-104.

23. Murphy AJ, Watsford ML, Coutts AJ et al. Effects of creatine supplementation on aerobic power and cardiovascular structure and function. J Sci Med Sport 2005; 8:305-313. 
24. Hickner RC, Dyck DJ, Sklar J et al. Effect of 28 days of creatine ingestion on muscle metabolism and performance of a simulated cycling road race. 2010;13.

25. Canete S, Earnest CP, Fleck SJ et al. Does creatine supplementation improve functional capacity in elderly women? Journal of strength and conditionning research 2006.

26. Carvalho APPF, Rassi S, Fontana KE et al. Influence of creatine supplementation on the functional capacity of patients with heart failure. Arq Bras Cardiol 2012; 99:623-629.

27. Poole DC, Jones AM. Measurement of the maximum oxygen uptake $\dot{\mathrm{V}}_{2 \text { max }}$ : $\dot{\mathrm{V}}_{2 \text { peak }}$ is no longer acceptable. J Appl Physiol 2017; 122:997-1002.

28. Scottish Intercollegiate Guidelines Network Sign 50: A Guideline Developer's Handbook. 2019; Available online: http://www.sign.ac.uk

29. PEDro Scale for Randomized Controlled Trials; Available online: https://pedro.org.au/

30. Lee DK, In J, Lee S. Standard deviation and standard error of the mean. Korean J Anesthesiol 2015; 68:220-223.

31. Wan X, Wang W, Liu J et al. Estimating the sample mean and standard deviation from the sample size, median, range and/or interquartile range. BMC Med Res Methodol 2014; $14: 135$.

32. Borenstein M, Hedges LV, Higgins JPT et al. Introduction to Meta-Analysis. 2009.

33. DerSimonian R, Laird N. Meta-analysis in clinical trials. Control Clin Trials 1986; 7:177188.

34. Cohen J. Statistical power analysis for the behavioral sciences. 2nd ed Hillsdale, N.J: L. Erlbaum Associates; 1988.

35. Smith A, Fukuda D, Ryan E et al. Ergolytic/Ergogenic Effects of Creatine on Aerobic Power. Int J Sports Med 2011; 32:975-981.

36. Reardon TF, Ruell PA, Fiatarone Singh MA et al. Creatine supplementation does not enhance submaximal aerobic training adaptations in healthy young men and women. Eur J Appl Physiol 2006; 98:234-241.

37. Kuethe F, Krack A, Richartz BM et al. Creatine supplementation improves muscle strength in patients with congestive heart failure. 2006;5.

38. Van Loon LJC, Oosterlaar AM, Hartgens F et al. Effects of creatine loading and prolonged creatine supplementation on body composition, fuel selection, sprint and endurance performance in humans. Clin Sci Lond Engl 1979 2003; 104:153-162.

39. Eijnde BO, Van Leemputte M, Goris $\mathrm{M}$ et al. Effects of creatine supplementation and exercise training on fitness in men 55-75 yr old. J Appl Physiol 2003; 95:818-828.

40. Sterkowicz S, Tyka AK, Chwastowski M et al. The effects of training and creatine malate supplementation during preparation period on physical capacity and special fitness in judo contestants. J Int Soc Sports Nutr 2012; 9:41.

41. Lázaro da Silveira C, Paiva de Souza TS, Batista GR et al. Is Long Term Creatine and Glutamine Supplementation Effective in Enhancing Physical Performance of Military Police Officers? J Hum Kinet 2014; 43:131-138.

42. Forbes SC, Sletten N, Durrer C et al. Creatine Monohydrate Supplementation Does Not Augment Fitness, Performance, or Body Composition Adaptations in Response to Four Weeks of High-Intensity Interval Training in Young Females. Int J Sport Nutr Exerc Metab 2017; 27:285-292.

43. Graef JL, Smith AE, Kendall KL et al. The effects of four weeks of creatine supplementation and high-intensity interval training on cardiorespiratory fitness: a randomized controlled trial. J Int Soc Sports Nutr 2009; 6:18.

44. Kresta JY, Oliver JM, Jagim AR et al. Effects of 28 days of beta-alanine and creatine supplementation on muscle carnosine, body composition and exercise performance in recreationally active females. J Int Soc Sports Nutr 2014; 11:55. 
45. Villanueva MG, He J, Schroeder ET. Periodized resistance training with and without supplementation improve body composition and performance in older men. Eur J Appl Physiol 2014; 114:891-905.

46. Barnett C, Hinds M, Jenkins DG. Effects of oral creatine supplementation on multiple sprint cycle performance. Aust J Sci Med Sport 1996; 28:35-39.

47. Lawrence SR, Preen DB, Dawson BT et al. The effect of oral creatine supplementation on maximal exercise performance in competitive rowers. Sports Med Train Rehabil 1997; 7:243-253.

48. Ebbeling CB, Ward A, Puleo EM et al. Development of a single-stage submaximal treadmill walking test. Med Sci Sports Exerc 1991; 23:966-973.

49. Beaver WL, Wasserman K, Whipp BJ. A new method for detecting anaerobic threshold by gas exchange. J Appl Physiol 1986; 60:2020-2027.

50. Wasserman K, Whipp BJ, Koyl SN et al. Anaerobic threshold and respiratory gas exchange during exercise. J Appl Physiol 1973; 35:236-243.

51. Harris RC, Söderlund K, Hultman E. Elevation of creatine in resting and exercised muscle of normal subjects by creatine supplementation. Clin Sci 1992; 83:367-374.

52. di Prampero PE, Ferretti G. Factors limiting maximal oxygen consumption in humans. Respir Physiol 1990; 80:113-128.

53. Casey A, Constantin-Teodosiu D, Howell $\mathrm{S}$ et al. Creatine ingestion favorably affects performance and muscle metabolism during maximal exercise in humans. Am J Physiol 1996; 271:E31-37.

54. Ipsiroglu OS, Stromberger C, Ilas J et al. Changes of tissue creatine concentrations upon oral supplementation of creatine-monohydrate in various animal species. Life Sci 2001; 69:1805-1815.

55. Siebenmann C, Rasmussen $P$, Sørensen $H$ et al. Cardiac output during exercise: A comparison of four methods: Determination of cardiac output during exercise. Scand J Med Sci Sports 2015; 25:e20-e27.

56. Gordon A, Hultman E, Kaijser L et al. Creatine supplementation in chronic heart failure increases skeletal muscle creatine phosphate and muscle performance. Cardiovasc Res 1995; 30:413-418.

57. Robinson TM, Sewell DA, Casey A et al. Dietary creatine supplementation does not affect some haematological indices, or indices of muscle damage and hepatic and renal function. Br J Sports Med 2000; 34:284-288.

58. Thompson CH, Kemp GJ, Sanderson AL et al. Effect of creatine on aerobic and anaerobic metabolism in skeletal muscle in swimmers. Br J Sports Med 1996; 30:222225.

59. Ivy JL, Withers RT, Van Handel PJ et al. Muscle respiratory capacity and fiber type as determinants of the lactate threshold. J Appl Physiol 1980; 48:523-527.

60. Reybrouck T, Ghesquiere J, Weymans M et al. Ventilatory Threshold Measurement to Evaluate Maximal Endurance Performance. Int J Sports Med 1986; 07:26-29.

61. Sjödin B, Jacobs I. Onset of blood lactate accumulation and marathon running performance. Int J Sports Med 1981; 2:23-26.

62. Mesa JLM, Ruiz JR, González-Gross MM et al. Oral creatine supplementation and skeletal muscle metabolism in physical exercise. Sports Med Auckl NZ 2002; 32:903944.

63. Hill DW, Rowell AL. Running velocity at VO2max. Med Sci Sports Exerc 1996; 28:114119.

64. Green AL, Hultman E, Macdonald IA et al. Carbohydrate ingestion augments skeletal muscle creatine accumulation during creatine supplementation in humans. Am J Physiol 1996; 271:E821-826. 
65. Forsberg AM, Nilsson E, Werneman J et al. Muscle composition in relation to age and sex. Clin Sci Lond Engl 1979 1991; 81:249-256.

66. Gibala MJ, Gillen JB, Percival ME. Physiological and Health-Related Adaptations to Low-Volume Interval Training: Influences of Nutrition and Sex. Sports Med Auckl Nz 2014; 44:127-137.

67. Devries MC, Phillips SM. Creatine Supplementation during Resistance Training in Older Adults-A Meta-analysis. Med Sci Sports Exerc 2014; 46:1194-1203.

68. Rawson ES, Volek JS. Effects of Creatine Supplementation and Resistance Training on Muscle Strength and Weightlifting Performance. J Strength Cond Res 2003.

69. Tabata I, NISHIMURA K, Kouzaki $M$ et al. Effects of moderate-intensity endurance and high-intensity intermittent training on anaerobic capacity and VO(2max). Med Sci Sports Exerc 1996; 28:1327-30.

70. Powers ME, Arnold BL, Weltman AL et al. Creatine Supplementation Increases Total Body Water Without Altering Fluid Distribution. J Athl Train 2003; 38:44-50.

71. McNaughton LR, Dalton B, Tarr J. The effects of creatine supplementation on highintensity exercise performance in elite performers. Eur J Appl Physiol 1998; 78:236-240.

72. Tyka AK, Chwastowski M, Cison T et al. Effect of creatine malate supplementation on physical performance, body composition and selected hormone levels in spinters and long-distance runners. Acta Physiol Hung 2015; 102:114-122.

73. LeLorier J, Grégoire G, Benhaddad A et al. Discrepancies between meta-analyses and subsequent large randomized, controlled trials. N Engl J Med 1997; 337:536-542.

74. Lacour JR, Flandrois R. [Role of aerobic metabolism in prolonged intensive exercise]. J Physiol (Paris) 1977; 73:89-130. 


\subsection{Figures and tables}

Fig 1. Search strategy

Fig 2. Quality of articles - SIGN checklist

Fig 3. Meta-analysis of aerobic changes after supplementation period between groups

Fig 4. Meta-regressions for the main outcome (VO2max)

Fig 5. Funnel plots of aerobic changes after supplementation period between groups

Table 1. Characteristics of included studies. 
Figure 1. Search strategy
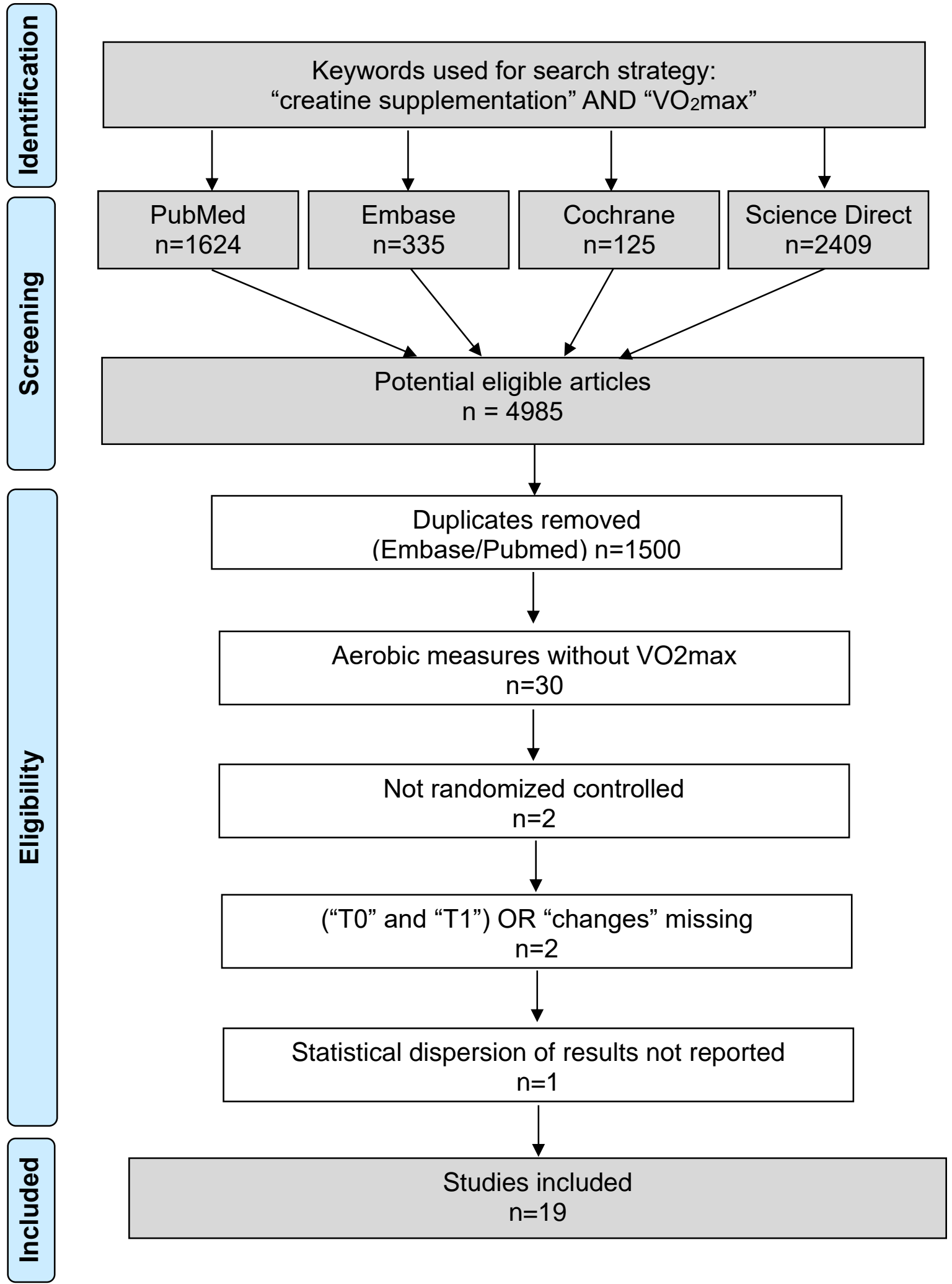
Figure 2. Quality of articles - SIGN checklist

\begin{tabular}{|c|c|c|c|c|c|c|c|c|c|c|c|}
\hline & \multicolumn{10}{|c|}{ Internal validity } & Quality \\
\hline Balsom 1993 & 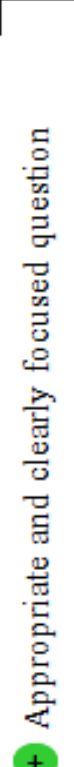 & 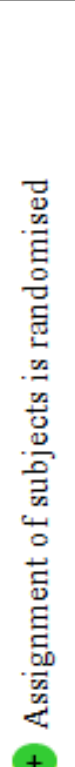 & 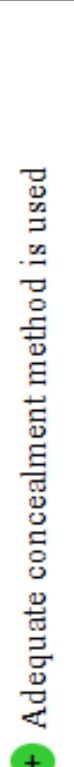 & 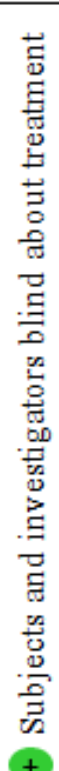 & 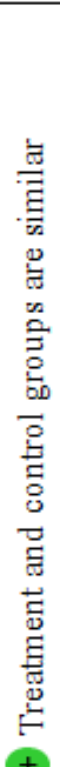 & 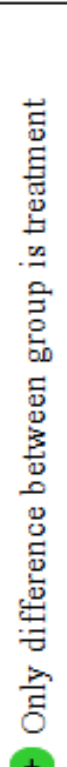 & 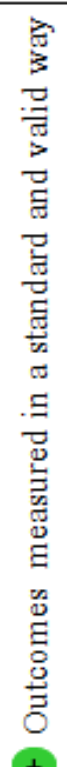 & 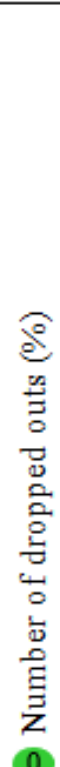 & 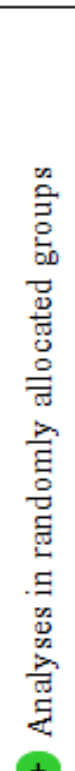 & 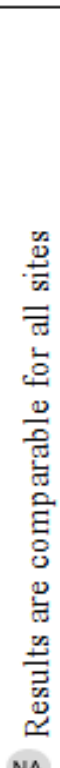 & 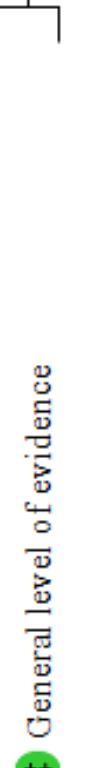 \\
\hline Barnett 1996 & + & $?$ & $?$ & + & + & + & + & 0 & + & NA & ++ \\
\hline Canete 2006 & + & $?$ & + & $\theta$ & + & + & + & 0 & + & NA & ++ \\
\hline Carvalho 2012 & + & $?$ & + & + & + & + & + & 0 & + & NA & ++ \\
\hline Da Silveira 2014 & + & $?$ & $?$ & + & + & + & C & 8 & + & NA & + \\
\hline Eijnde 2003 & + & $?$ & + & + & + & + & + & 0 & + & NA & ++ \\
\hline Forbes 2017 & + & + & + & + & + & + & + & 6 & + & NA & ++ \\
\hline Graef 2009 & + & $?$ & $?$ & + & + & + & + & 0 & + & NA & ++ \\
\hline Hickner 2010 & + & $?$ & $?$ & + & + & + & + & 0 & + & NA & + \\
\hline Kresta 2014 & + & $?$ & $?$ & + & + & + & + & 9 & + & NA & ++ \\
\hline Kuethe 2006 & + & $?$ & $?$ & + & + & + & + & 35 & + & NA & + \\
\hline Lawrence 1996 & + & $?$ & $?$ & + & $\oplus$ & + & + & 0 & + & NA & ++ \\
\hline Murphy 2005 & + & $?$ & $?$ & + & + & + & + & 0 & + & NA & ++ \\
\hline Nelson 2000 & + & $?$ & $?$ & + & + & + & + & 28 & + & NA & + \\
\hline Reardon 2006 & + & $?$ & $?$ & $\sigma$ & + & + & + & 23 & + & NA & + \\
\hline Smith 2011 & + & $?$ & $?$ & + & + & + & + & 0 & + & NA & ++ \\
\hline Sterkowicz 2012 & + & $?$ & $?$ & + & - & + & + & 0 & + & NA & + \\
\hline Van Loon 2003 & + & + & + & + & + & + & + & 5 & + & NA & ++ \\
\hline Villanueva 2014 & + & $?$ & $?$ & + & $\oplus$ & + & & 0 & + & NA & + \\
\hline
\end{tabular}


Figure 3. Meta-analyses of changes between groups

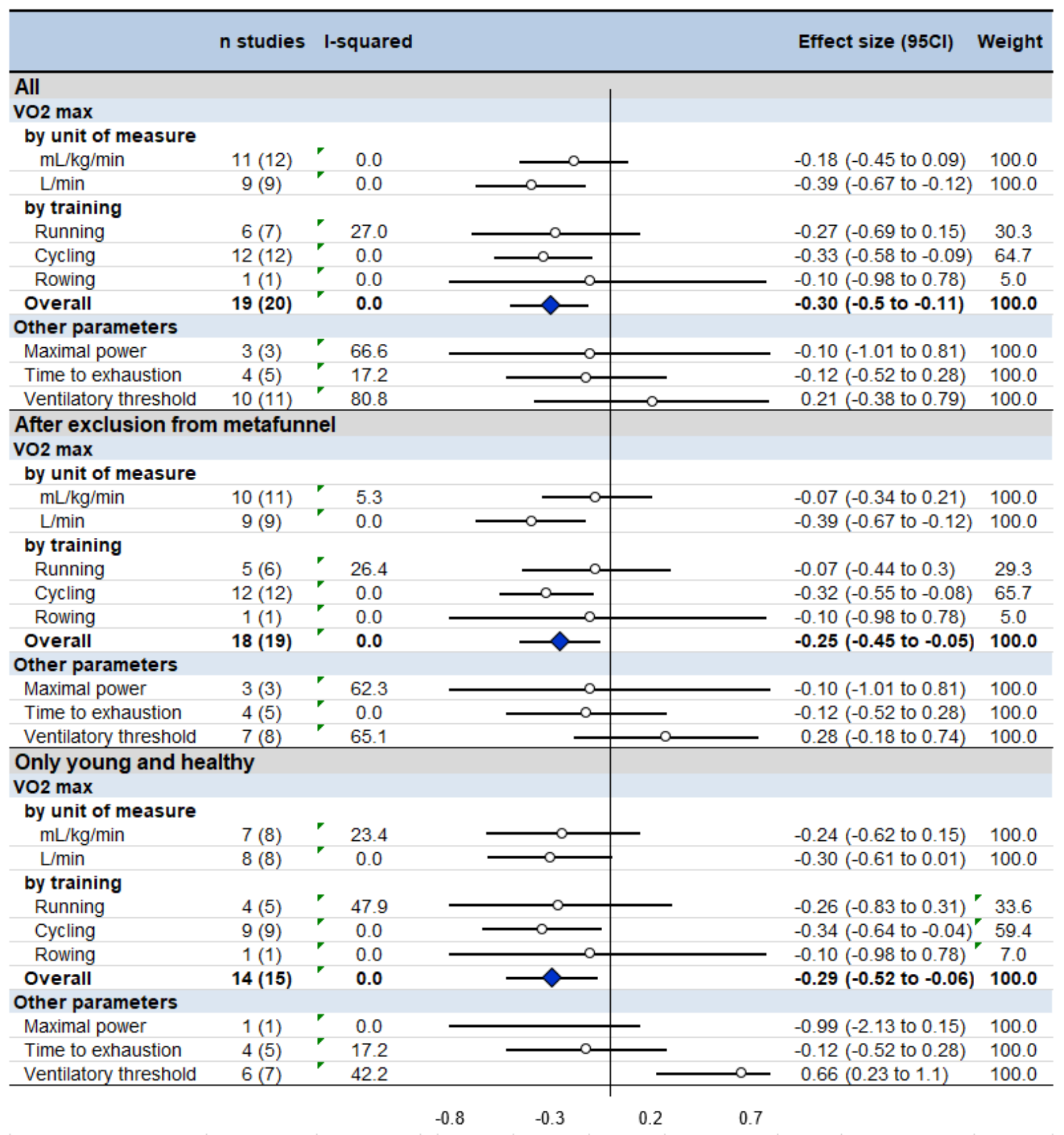

Figure 3. Meta-analysis of changes between groups for all studies and sensitivity analyses: $\mathrm{VO}_{2}$ max (stratified by unit of measure and by type of training), maximal aerobic performances (time to exhaustion and maximal power output) and ventilatory threshold. Cr group as reference. 


\section{Figure 4. Meta-regressions}

\begin{tabular}{|c|c|c|c|}
\hline & & Effect size $(95 \mathrm{Cl})$ & $p$-value \\
\hline \multicolumn{4}{|l|}{ Changes between groups } \\
\hline \multicolumn{4}{|l|}{ Performance at To } \\
\hline VO2max (per $0.1 \mathrm{~L} / \mathrm{min}$ ) & $p$ & $0.08(-0.02$ to 0.02$)$ & 0.122 \\
\hline \multicolumn{4}{|l|}{ Population } \\
\hline Age (per ten-year) & d. & $-0.03(-0.15$ to 0.08$)$ & 0.572 \\
\hline Sex (per ten-percent male) & & $-0.02(-0.08$ to 0.03$)$ & 0.351 \\
\hline \multicolumn{4}{|l|}{ Physical activity at baseline } \\
\hline competition vs recreation & $-\infty$ & $0.23(-0.47$ to 0.93$)$ & 0.494 \\
\hline competition vs sedentary & $+\infty$ & $0.37(-0.38$ to 1.13$)$ & 0.309 \\
\hline recreation vs sedentary & $-\infty$ & $0.14(-0.34$ to 0.63$)$ & 0.544 \\
\hline \multirow{2}{*}{\multicolumn{4}{|c|}{$\begin{array}{l}\text { Health condintion (Healtny as reference) } \\
\text { Supplementation }\end{array}$}} \\
\hline & & & \\
\hline Loading dose (posology per 20-gr) & -1 & $0.01(-0.43$ to 0.46$)$ & 0.923 \\
\hline Loading dose (duration per 7-day) & - & $0.06(-0.27$ to 0.14$)$ & 0.514 \\
\hline Maintenance dose (posology per 1-gr) & & $-0.02(-0.08$ to 0.04$)$ & 0.563 \\
\hline Total dose (per 100-gr) & d & $-0.02(-0.1$ to 0.04$)$ & 0.387 \\
\hline Total duration (per 30-day) & 9 & $-0.03(-0.13$ to 0.07$)$ & 0.547 \\
\hline \multicolumn{4}{|l|}{ Training during supplementation } \\
\hline aerobic vs anaerobic & - & $-0.18(-0.78$ to 0.42$)$ & 0.534 \\
\hline aerobic vs none & - & $-0.11(-0.64$ to 0.41$)$ & 0.656 \\
\hline anaerobic vs none & $b=$ & $0.07(-0.63$ to 0.76$)$ & 0.841 \\
\hline \multicolumn{4}{|l|}{ T1 creat vs T1 control } \\
\hline \multicolumn{4}{|l|}{ Performance at TO } \\
\hline VO2max (per $0.1 \mathrm{~L} / \mathrm{min}$ ) & - & $0.06(-0.04$ to 0.2$)$ & 0.218 \\
\hline \multicolumn{4}{|l|}{$\begin{array}{l}\text { VO2max (per } 0.1 \mathrm{~L} / \mathrm{min} \text { ) } \\
\text { Population }\end{array}$} \\
\hline Age (per ten-year) & - & $0.05(-0.07$ to 0.16$)$ & 0.407 \\
\hline Sex (per ten-percent male) & & $-0.03(-0.08$ to 0.03$)$ & 0.304 \\
\hline \multicolumn{4}{|l|}{ Physical activity at baseline } \\
\hline competition vs recreation & - & $-0.03(-0.66$ to 0.59$)$ & 0.896 \\
\hline competition vs sedentary & & $0.04(-0.65$ to 0.73$)$ & 0.896 \\
\hline recreation vs sedentary & - & $0.08(-0.42$ to 0.55$)$ & 0.789 \\
\hline Health condition (Healthy as reference) & & insufficient data & \\
\hline \multicolumn{4}{|l|}{ Supplementation } \\
\hline Loading dose (posology per 20-gr) & -0 & $0.02(-0.4$ to 0.4$)$ & 0.916 \\
\hline Loading dose (duration per 7-day) & $-\alpha$ & $-0.03(-0.21$ to 0.14$)$ & 0.788 \\
\hline Maintenance dose (posology per 1-gr) & & $-0.01(-0.07$ to 0.05$)$ & 0.705 \\
\hline Total dose (per 100-gr) & & $-0.01(-0.08$ to 0.05$)$ & 0.664 \\
\hline Total duration (per 30-day) & & $-0.02(-0.12$ to 0.07$)$ & 0.648 \\
\hline \multicolumn{4}{|l|}{ Training during supplementation } \\
\hline aerobic vs anaerobic & 一 & $-0.26(-0.86$ to 0.33$)$ & 0.361 \\
\hline aerobic vs none & - & $-0.19(-0.72$ to 0.33$)$ & 0.446 \\
\hline anaerobic vs none & & $0.07(-0.63$ to 0.77$)$ & 0.833 \\
\hline
\end{tabular}

$\begin{array}{llll}\text { T1 creatine vs To creatine } & & \\ \text { Performance at To } \\ \text { VO2max (per 0.1 L/min) }\end{array}$


Fig 5. Funnel plots

\section{$\mathrm{VO}_{2}$ max changes stratified by training"}

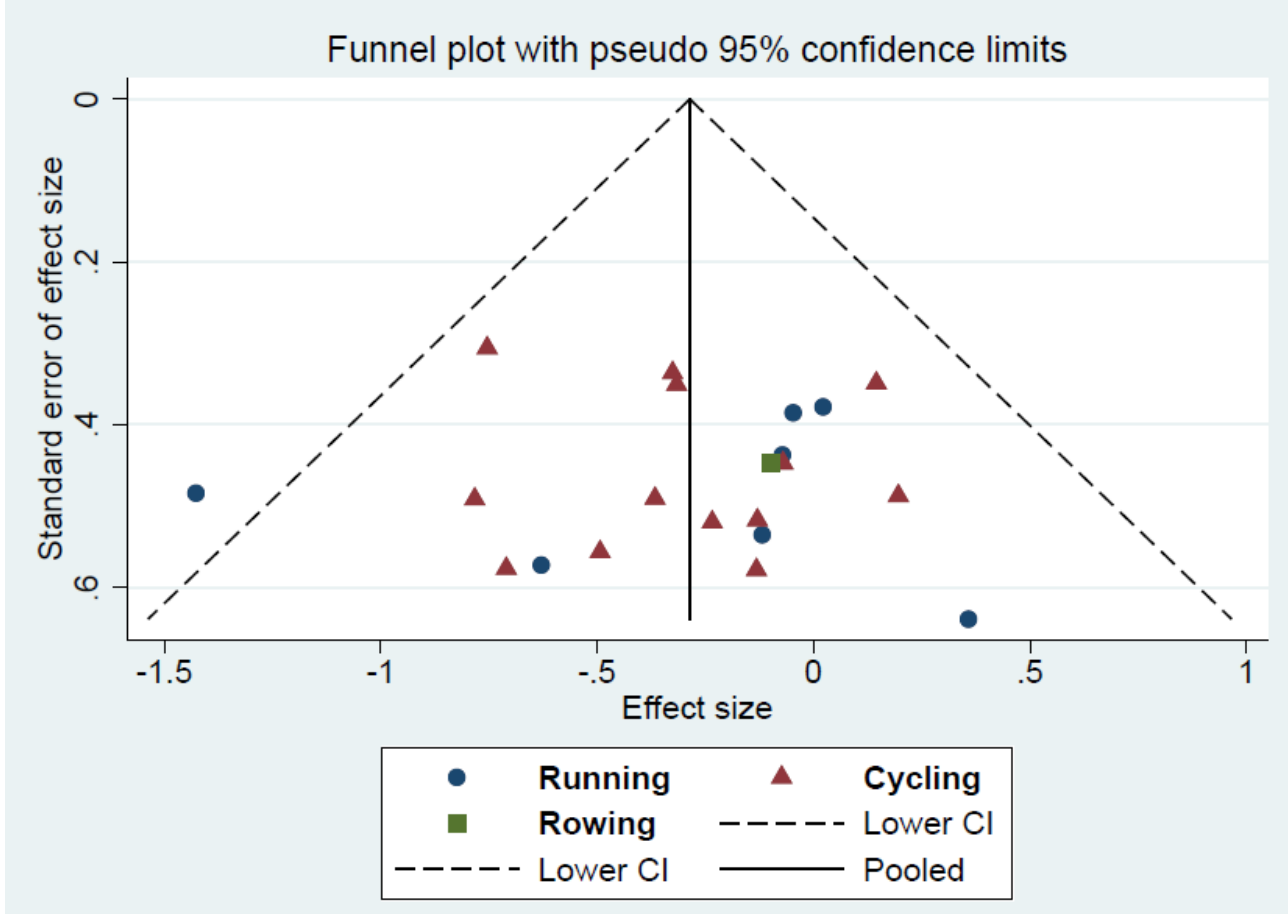

"Aerobic" changes

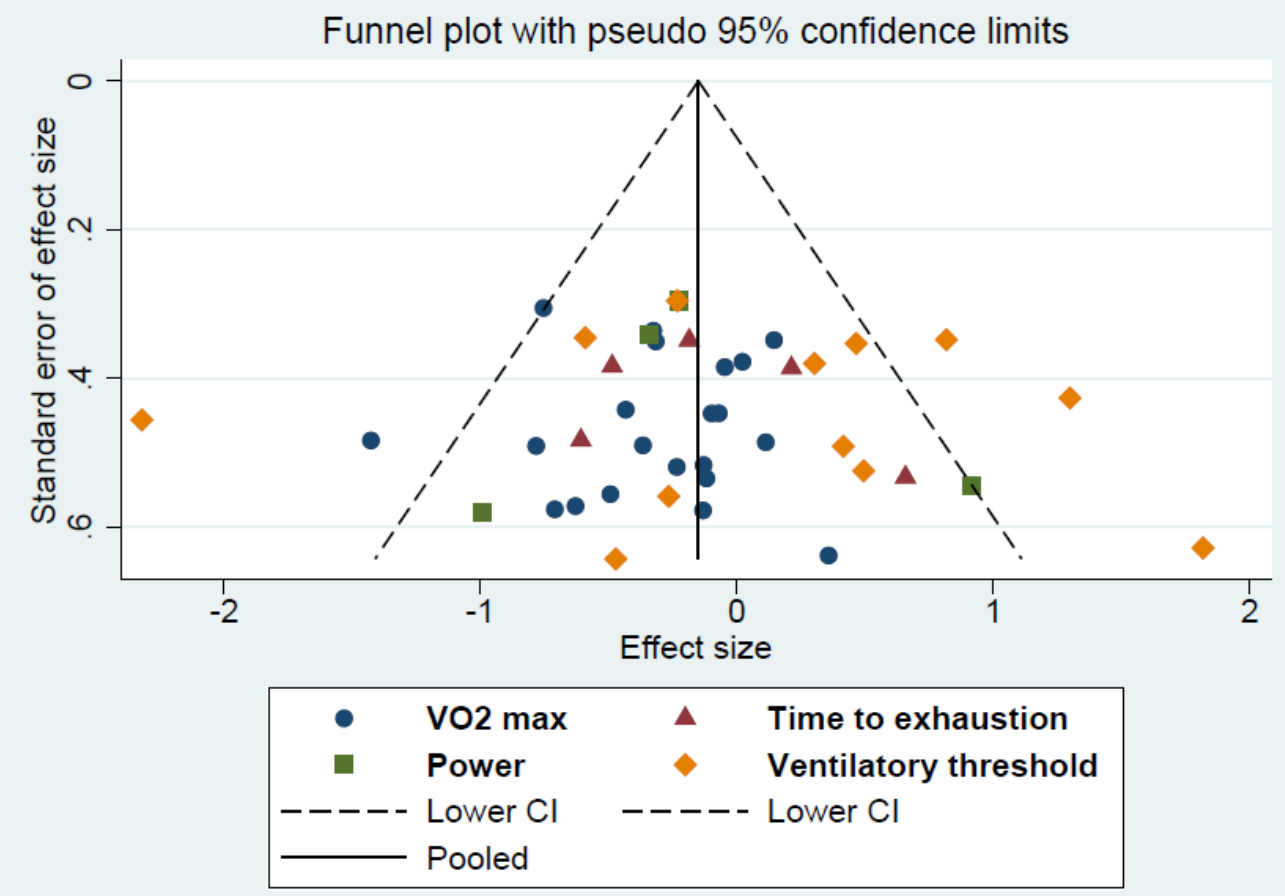


Table 1. Characteristics of included studies

\begin{tabular}{|c|c|c|c|c|c|c|c|c|c|c|c|c|c|}
\hline & Study & & & & Populati & & $\begin{array}{c}\text { Outcome } \\
\text { measurement }\end{array}$ & & & Intervention & & & \\
\hline Author & Year & Country & $\begin{array}{c}\text { Total } \\
\text { (n) }\end{array}$ & $\begin{array}{c}\text { Men } \\
(\%)\end{array}$ & $\begin{array}{c}\text { Age } \\
\text { (mean or } \\
\text { interval) }\end{array}$ & $\begin{array}{c}\text { Physical level } \\
\text { activity }\end{array}$ & $\begin{array}{c}\text { Incremental } \\
\text { test }\end{array}$ & $\begin{array}{c}\text { Training } \\
\text { intervention }\end{array}$ & Type Cr & $\begin{array}{c}\text { Loading dose } \\
\text { (g/day - n/day - } \\
\text { n days) }\end{array}$ & $\begin{array}{c}\text { Maintenance } \\
\text { dose (g/day - } \\
\text { n/day - n days) }\end{array}$ & $\begin{array}{l}\text { Total } \\
\text { dose }\end{array}$ & Other assessments \\
\hline Balsom & 1993 & Sweden & 14 & 100 & $19-37$ & $\begin{array}{l}\text { Competition } \\
\text { (mid-distance } \\
\text { runners) } \\
\end{array}$ & Running & Aerobic & Cr monohydrate & 0 & $5-1-6$ & 30 & \\
\hline Barnett & 1996 & Australia & 17 & 100 & 20,5 & Recreation & Cycling & Aerobic & Cr monohydrate & 0 & $5-4-4$ & 20 & \\
\hline Canete & 2006 & USA & 16 & 0 & 68 & Sedentary & Cycling & None & Cr monohydrate & $19-3-7$ & 0 & 130 & \\
\hline Carvalho & 2012 & Brazil & 33 & 100 & 55,7 & $\begin{array}{c}\text { Sedentary (heart } \\
\text { failure) }\end{array}$ & Cycling & None & No information & 0 & $5-1-180$ & 900 & \\
\hline Da Silveira & 2014 & Brazil & 22 & 100 & $18-30$ & $\begin{array}{l}\text { Competition } \\
\text { (military) }\end{array}$ & Running & $\begin{array}{c}\text { Aerobic } \\
\text { (MTP) }\end{array}$ & Cr monohydrate & $25-3-7$ & $2,5-1-86$ & 385 & \\
\hline Eijnde & 2003 & Netherlands & 46 & 100 & $55-75$ & Sedentary & Cycling & $\begin{array}{l}\text { Aerobic } \\
(\mathrm{FTP})\end{array}$ & Cr monohydrate & 0 & $5-5-182$ & 910 & $\begin{array}{c}\text { muscle biopsy, body } \\
\text { composition }\end{array}$ \\
\hline Forbes & 2017 & Canada & 17 & 0 & 23 & Recreation & Cycling & $\begin{array}{l}\text { Anaerobic } \\
\text { (HIIT) }\end{array}$ & Cr monohydrate & $19-2-5$ & $6,5-1-23$ & 245 & body composition \\
\hline Graef & 2009 & USA & 33 & 100 & 22,6 & Recreation & Cycling & $\begin{array}{l}\text { Anaerobic } \\
\text { (HIIT) }\end{array}$ & di-Cr citrate & 0 & $10-2-30$ & 300 & \\
\hline Hickner & 2010 & USA & 12 & 100 & 27,2 & $\begin{array}{l}\text { Recreation } \\
\text { (cyclists) }\end{array}$ & Cycling & Aerobic & Cr monohydrate & 0 & $3-1-28$ & 84 & $\begin{array}{c}\text { muscle biopsy, body } \\
\text { composition }\end{array}$ \\
\hline Kresta & 2014 & USA & 15 & 0 & 21,5 & Recreation & Cycling & Aerobic & Cr monohydrate & $18-4-7$ & $6-1-21$ & 252 & $\begin{array}{c}\text { muscle biopsy, body } \\
\text { composition }\end{array}$ \\
\hline Kuethe & 2006 & Germany & 13 & 75 & 58,2 & $\begin{array}{l}\text { Sedentary (heart } \\
\text { failure) }\end{array}$ & Walking & None & No information & $20-4-42$ & 0 & 840 & \\
\hline Lawrence & 1996 & Australia & 20 & 50 & 21,2 & $\begin{array}{l}\text { Competition } \\
\text { (elite rowers) }\end{array}$ & Rowing & Aerobic & Cr monohydrate & $18-4-5$ & 0 & 92 & \\
\hline Murphy & 2005 & Australia & 18 & 100 & 24 & $\begin{array}{c}\text { Recreation } \\
\text { (team sports) }\end{array}$ & Cycling & Aerobic & Cr monohydrate & $20-4-7$ & $10-2-21$ & 350 & \\
\hline Nelson & 2000 & USA & 36 & 55 & 23,5 & Recreation & Cycling & Aerobic & Cr monohydrate & $20-4-7$ & 0 & 140 & \\
\hline Reardon & 2006 & Australia & 13 & 70 & $19-22$ & Recreation & Cycling & Aerobic & Cr monohydrate & $20-4-7$ & $5-1-21$ & 168 & $\begin{array}{c}\text { muscle biopsy, body } \\
\text { composition }\end{array}$ \\
\hline Smith & 2011 & USA & 27 & 100 & 22,2 & Recreation & Running & Aerobic & di-Cr citrate & $20-4-5$ & 0 & 100 & \\
\hline Smith & 2011 & USA & 28 & 0 & 21,2 & Recreation & Running & Aerobic & di-Cr citrate & $20-4-5$ & 0 & 100 & \\
\hline Sterkowicz & 2012 & Poland & 10 & 100 & 21,2 & $\begin{array}{l}\text { Competition } \\
\text { (judoists) }\end{array}$ & Running & Aerobic & $\mathrm{Cr}$ malate & 0 & $5-1-42$ & 210 & body composition \\
\hline
\end{tabular}




\begin{tabular}{cccccccccccccc}
\hline Van Loon & 2003 & Netherlands & 20 & 100 & 20,6 & Sedentary & Cycling & None & Cr monohydrate & $20-4-5$ & 2 & 174 & $\begin{array}{c}\text { muscle biopsy, body } \\
\text { composition }\end{array}$ \\
\hline Villanueva & 2014 & USA & 14 & 100 & 68,1 & Recreation & Cycling & Aerobic & Cr monohydrate & $24-3-5$ & $5,5-1-79$ & 552 & body composition \\
\hline
\end{tabular}

FTP=fitness training program; HIIT=high intensity interval training; $M T P=$ military training program 


\section{S1 Appendix. Details for the search strategy used within each database.}

\section{Pubmed}

("Cr"[MH] OR "Cr"[TW]) AND ("physical conditioning, human"[MH] OR "physical conditioning"[TW] OR "physical training"[TW] OR "training"[Title] OR "physical endurance"[MH] OR "physical endurance"[TW] OR "endurance, physical"[TW] OR "endurance"[Title] OR "physical stamina"[TW] OR "Sports"[Mesh] OR Sport*[TW] OR "Sports Nutritional Sciences"[Mesh] OR "exercise test"[MESH] OR "exercise"[MH] OR exercise*[TW] OR "activities, physical"[TW] OR "activity, physical"[TW] OR "physical activities"[TW] OR "physical activity"[TW] OR "athletes"[MH] OR "athletes"[TW] OR "athlete"[TW] OR "athletic performance"[MH] OR (performance*[TW] AND (Athlet*[TW] OR sport*[TW] OR fitness[TW] OR physical*[TW])) OR "physical fitness"[MH] OR "fitness, physical"[TW] OR "physical fitness"[TW] OR "oxygen consumption"[MH] OR "oxygen consumptions"[TW] OR "oxygen consumption"[TW] OR "oxygen requirement"[TW] OR "consumption, oxygen"[TW] OR VO2[TW] OR VO2max[TW] OR VO2peak[TW]) AND ("dietary supplements"[MH] OR supplement*[TW] OR "neutraceuticals"[TW] OR "nutraceutical food"[TW] OR "trace elements"[TW]) NOT (animals[MeSH Terms] NOT humans[MeSH Terms])

Filter Language $=$ none $;$ Filter Dates $=$ none

Results $=1624$

\section{Cochrane Library (combining searching on Embase databases)}

\#1 "Cr":ti,ab,kw

\#2 "physical conditioning":ti,ab,kw OR "physical training":ti,ab,kw OR "training":ti OR "physical endurance":ti,ab,kw OR "endurance, physical":ti,ab,kw OR "endurance":ti OR "physical stamina":ti,ab,kw OR Sport*:ti,ab,kw OR exercise*:ti,ab,kw OR "activities, physical":ti,ab,kw OR "activity, physical":ti,ab,kw OR "physical activities":ti,ab,kw OR "physical activity":ti,ab,kw OR "athletes":ti,ab,kw OR "athlete":ti,ab,kw OR (performance*:ti,ab,kw AND (Athlet*:ti,ab,kw OR sport*:ti,ab,kw OR fitness:ti,ab,kw OR physical*:ti,ab,kw)) OR "fitness, physical":ti,ab,kw OR "physical fitness":ti,ab,kw OR "oxygen consumptions":ti,ab,kw OR "oxygen consumption":ti,ab,kw OR "oxygen requirement":ti,ab,kw OR "consumption, oxygen":ti,ab,kw OR VO2:ti,ab,kw OR VO2max:ti,ab,kw OR VO2peak:ti,ab,kw

\#3 supplement*:ti,ab,kw OR "neutraceuticals":ti,ab,kw OR "nutraceutical food":ti,ab,kw OR "trace elements":ti,ab,kw

\#4 \#1 AND \#2 AND \#3

Filter Language $=$ not available in CENTRAL ; Filter Dates $=$ none

Results $=956$

\section{ScienceDirect:}

"CS" AND ("VO2max" OR "VO2peak" OR "maximal oxygen consumption")

Filter Language $=$ none $;$ Filter Dates $=$ none

Results $=2409$ 


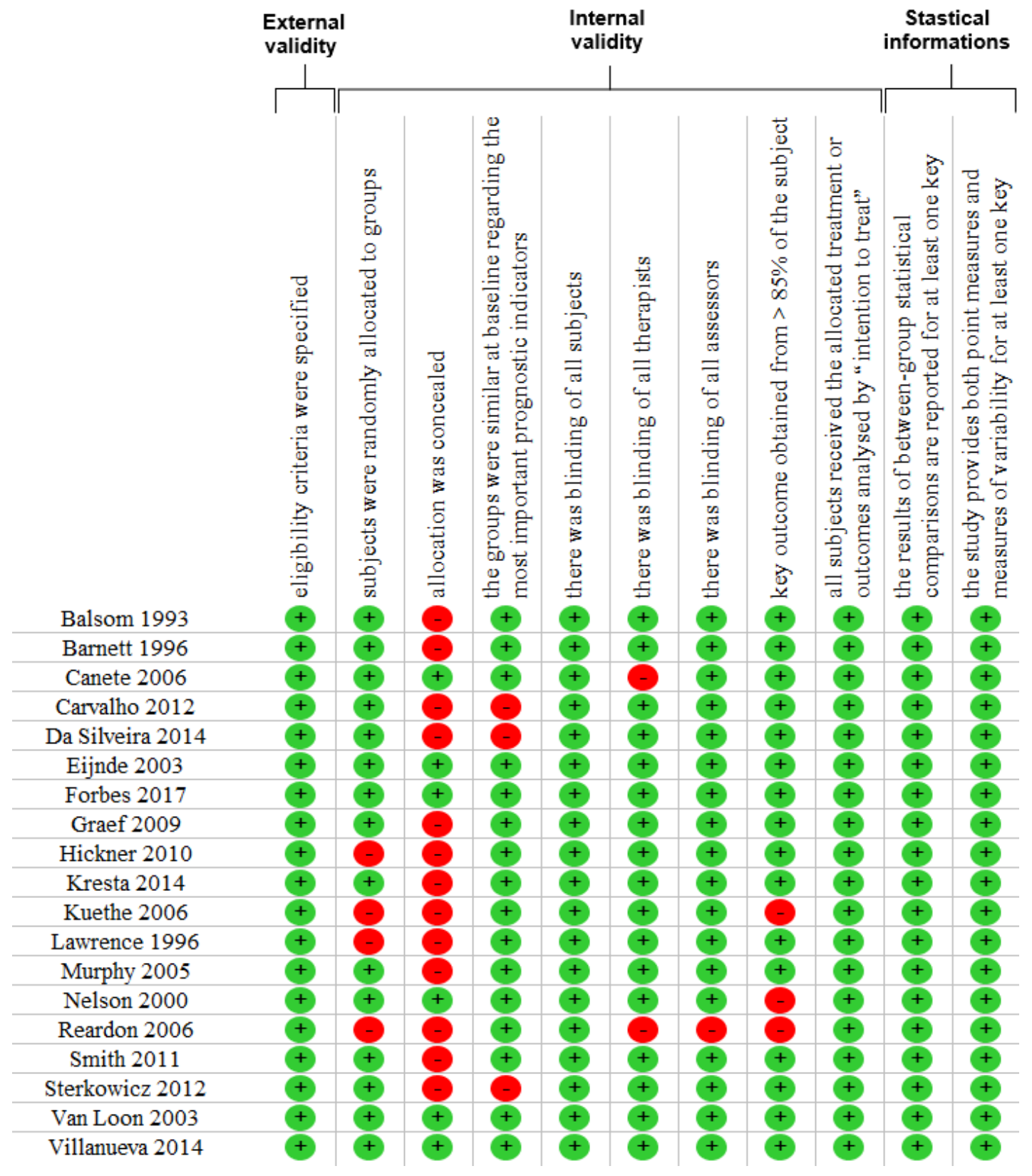


S3 Appendix. Forest plot of aerobic changes in the Cr group compared to the control group within studies included following the supplementation period

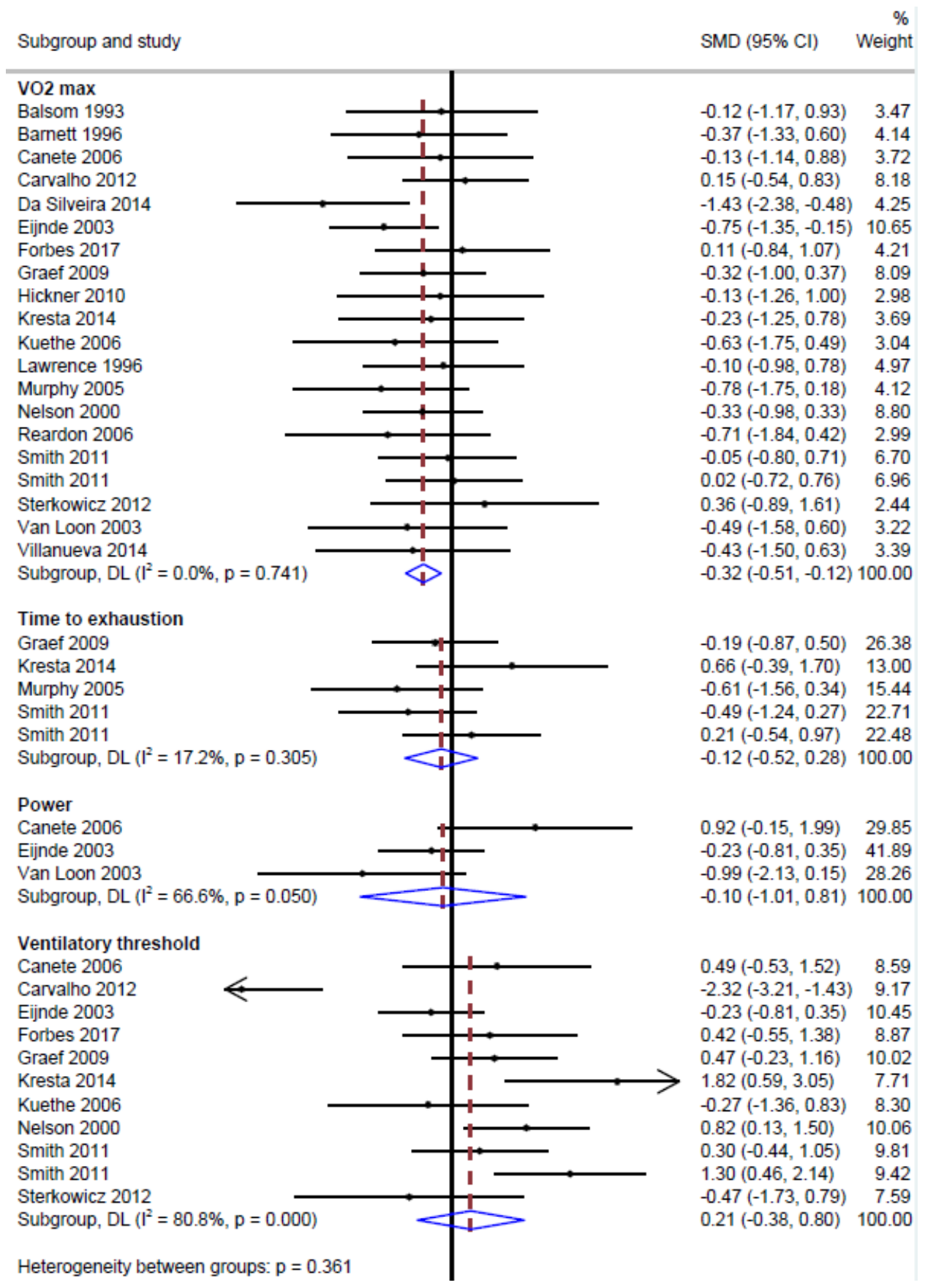


S4 Appendix. Meta-analyses of aerobic measures at baseline and at $\mathrm{T} 1$ between groups, and between $\mathrm{T} 0$ and $\mathrm{T} 1$ within groups for all studies.

\begin{tabular}{|c|c|c|c|c|c|c|}
\hline & n studies & I-squared & & & Effect size (95Cl) & Weight \\
\hline \multicolumn{7}{|c|}{ T1 creat vs T1 control } \\
\hline \multicolumn{7}{|l|}{ VO2 $\max$} \\
\hline \multicolumn{7}{|l|}{ by unit of measure } \\
\hline $\mathrm{mL} / \mathrm{kg} / \mathrm{min}$ & $11(12)$ & 5.3 & & & $-0.06(-0.33$ to 0.22$)$ & 100.0 \\
\hline $\mathrm{L} / \mathrm{min}$ & $9(9)$ & 0.0 & - & & $-0.32(-0.59$ to -0.04$)$ & 100.0 \\
\hline \multicolumn{7}{|l|}{ by training } \\
\hline Running & $6(7)$ & 26.4 & & & $-0.19(-0.62$ to 0.23$)$ & 30.3 \\
\hline Cycling & $12(12)$ & 0.0 & & & $-0.22(-0.46$ to 0.02$)$ & 64.8 \\
\hline Rowing & $1(1)$ & 0.0 & & & $-0.04(-0.92$ to 0.83$)$ & 4.9 \\
\hline Overall & $19(20)$ & 0.0 & & & $-0.20(-0.39$ to -0.00 & 100.0 \\
\hline \multicolumn{7}{|l|}{ Other parameters } \\
\hline Maximal power & $3(3)$ & ' 62.3 & & & $-0.17(-1.02$ to 0.7$)$ & 100.0 \\
\hline Time to exhaustion & $4(5)$ & 0.0 & & & $-0.06(-0.42$ to 0.3$)$ & 100.0 \\
\hline Ventilatory threshold & $10(11)$ & $\quad 65.1$ & & - & $0.13(-0.3$ to 0.56$)$ & 100.0 \\
\hline \multicolumn{7}{|c|}{ T1 creat vs T0 creat } \\
\hline \multicolumn{7}{|l|}{ VO2 max } \\
\hline \multicolumn{7}{|l|}{ by unit of measure } \\
\hline $\mathrm{mL} / \mathrm{kg} / \mathrm{min}$ & $11(12)$ & 0.0 & & & $0.25(-0.01$ to 0.51$)$ & 100.0 \\
\hline $\mathrm{L} / \mathrm{min}$ & $9(9)$ & 0.0 & & - & $0.15(-0.11$ to 0.42$)$ & 100.0 \\
\hline \multicolumn{7}{|l|}{ by training } \\
\hline Running & $6(7)$ & > 26.4 & & & $0.25(-0.1$ to 0.6$)$ & 29.1 \\
\hline Cycling & $12(12)$ & 0.0 & & $\infty$ & $0.16(-0.07$ to 0.4$)$ & 66.2 \\
\hline Rowing & $1(1)$ & 0.0 & & $+\infty$ & $0.08(-0.8$ to 0.96$)$ & 4.7 \\
\hline Overall & $19(20)$ & 0.0 & & م & $0.18(-0.01$ to 0.37$)$ & 100.0 \\
\hline \multicolumn{7}{|l|}{ Other parameters } \\
\hline Maximal power & $3(4)$ & 0.0 & & $-\infty$ & $0.45(0.03$ to 0.88$)$ & 100.0 \\
\hline Time to exhaustion & $4(5)$ & 0.0 & & $-\infty$ & $0.14(-0.22$ to 0.5$)$ & 100.0 \\
\hline Ventilatory threshold & $10(12)$ & 22.2 & & $+\infty$ & $0.22(-0.05$ to 0.5$)$ & 100.0 \\
\hline \multicolumn{7}{|c|}{ T1 control vs T0 control } \\
\hline \multicolumn{7}{|l|}{ VO2 $\max$} \\
\hline \multicolumn{7}{|l|}{ by unit of measure } \\
\hline $\mathrm{mL} / \mathrm{kg} / \mathrm{min}$ & $11(12)$ & 0.0 & & $\rightarrow$ & 0.35 (0.08 to 0.62$)$ & 100.0 \\
\hline $\mathrm{L} / \mathrm{min}$ & $9(9)$ & 0.0 & & & 0.36 (0.08 to 0.63$)$ & 100.0 \\
\hline \multicolumn{7}{|l|}{ by training } \\
\hline Running & $6(7)$ & r 29.0 & & & $0.38(-0.05 \text { to } 0.82)^{\prime}$ & 30.2 \\
\hline Cycling & $12(12)$ & 0.0 & & - & 0.35 (0.11 to 0.59$)$ & 64.8 \\
\hline Rowing & $1(1)$ & 0.0 & & & $0.15(-0.73 \text { to } 1.03)^{n}$ & 5.0 \\
\hline Overall & $19(20)$ & 0.0 & & $\longrightarrow$ & 0.35 (0.15 to 0.54$)$ & 100.0 \\
\hline \multicolumn{7}{|l|}{ Other parameters } \\
\hline Maximal power & $3(3)$ & ' 14.9 & & & $0.41(-0.11$ to 0.94$)$ & 100.0 \\
\hline Time to exhaustion & $4(5)$ & 0.0 & & - - & $0.20(-0.16$ to 0.56$)$ & 100.0 \\
\hline Ventilatory threshold & $10(11)$ & 59.3 & & $-\infty$ & $0.08(-0.32$ to 0.47$)$ & 100.0 \\
\hline \multicolumn{7}{|c|}{ TO creat vs TO control } \\
\hline \multicolumn{7}{|c|}{ VO2 max } \\
\hline by unit of measure & & & & & & \\
\hline $\mathrm{mL} / \mathrm{kg} / \mathrm{min}$ & $11(11)$ & 0.0 & & & $0.06(-0.2$ to 0.33$)$ & 100.0 \\
\hline $\mathrm{L} / \mathrm{min}$ & $9(10)$ & 0.0 & - & - & $-0.13(-0.4$ to 0.14$)$ & 100.0 \\
\hline by training & & & & & & \\
\hline Running & $6(7)$ & ' 13.0 & & & $0.01(-0.37$ to 0.39$)$ & 30.2 \\
\hline Cycling & $12(12)$ & 0.0 & 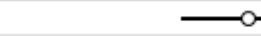 & - & $-0.07(-0.31$ to 0.17$)$ & 64.9 \\
\hline Rowing & $1(1)$ & 0.0 & & & $0.00(-0.88$ to 0.88$)$ & 4.9 \\
\hline Overall & $19(20)$ & 0.0 & & - & $-0.04(-0.23$ to 0.15$)$ & 100.0 \\
\hline Other parameters & & & & & & \\
\hline Maximal power & $3(3)$ & 0.0 & 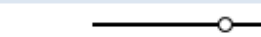 & & $-0.15(-0.61$ to 0.3$)$ & 100.0 \\
\hline Time to exhaustion & $4(5)$ & 0.0 & & & $0.00(-0.36$ to 0.36$)$ & 100.0 \\
\hline Ventilatory threshold & $10(11)$ & $\quad 31.1$ & 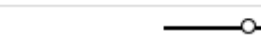 & - & $-0.07(-0.37$ to 0.23$)$ & 100.0 \\
\hline & & & -0.8 & 0.2 & & \\
\hline
\end{tabular}


S5 Appendix. Meta-analyses of aerobic measures at baseline and at $\mathrm{T} 1$ between groups, and between $\mathrm{T} 0$ and $\mathrm{T} 1$ within groups after exclusions from meta funnels.

\begin{tabular}{|c|c|c|c|c|c|c|}
\hline & n studies & I-squared & After exclusio & $\mathrm{n}$ from metafunnel & Effect size $(95 \mathrm{Cl})$ & Weight \\
\hline \multicolumn{7}{|c|}{ T1 creat vs T1 control } \\
\hline \multirow{2}{*}{\multicolumn{7}{|c|}{ VO2 max }} \\
\hline \multicolumn{2}{|l|}{ by unit of measure } & & & & & \\
\hline $\mathrm{mL} / \mathrm{kg} / \mathrm{min}$ & $10(11)$ & 0.0 & & & $0.00(-0.27$ to 0.27$)$ & 100.0 \\
\hline $\mathrm{L} / \mathrm{min}$ & $9(9)$ & 0.0 & $\longrightarrow$ & & $-0.32(-0.59$ to -0.04$)$ & 100.0 \\
\hline \multicolumn{7}{|l|}{ by training } \\
\hline Running & $5(6)$ & 0.0 & & & $-0.07(-0.45$ to 0.31$)$ & 29.3 \\
\hline Cycling & $12(12)$ & 0.0 & - & - & $-0.33(-0.58$ to 0.09$)$ & 65.7 \\
\hline Rowing & $1(1)$ & 0.0 & & & $-0.10(-0.97$ to 0.78$)$ & 5.0 \\
\hline Overall & $18(19)$ & 0.0 & & 1 & $-0.17(-0.36$ to 0.03$)$ & 100.0 \\
\hline \multicolumn{7}{|l|}{ Other parameters } \\
\hline Maximal power & $3(3)$ & 62.3 & 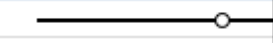 & & $-0.17(-1.02$ to 0.69$)$ & 100.0 \\
\hline Time to exhaustion & $4(5)$ & $\quad 0.0$ & & & $-0.06(-0.42$ to 0.3$)$ & 100.0 \\
\hline Ventilatory threshold & $7(8)$ & 0.0 & & $-\infty$ & $0.08(-0.19$ to 0.35$)$ & 100.0 \\
\hline \multicolumn{7}{|l|}{ T1 creat vs T0 creat } \\
\hline \multicolumn{7}{|l|}{ VO2 max } \\
\hline \multicolumn{7}{|l|}{ by unit of measure } \\
\hline $\mathrm{mL} / \mathrm{kg} / \mathrm{min}$ & $11(12)$ & 0.0 & & & $0.25(-0.01$ to 0.51$)$ & 100.0 \\
\hline $\mathrm{L} / \mathrm{min}$ & $9(9)$ & 0.0 & & $\infty$ & $0.15(-0.11$ to 0.42$)$ & 100.0 \\
\hline \multicolumn{7}{|l|}{ by training } \\
\hline Running & $6(7)$ & 0.0 & & & $0.27(-0.07$ to 0.61$)$ & 29.1 \\
\hline Cycling & $12(12)$ & 0.0 & & 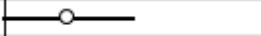 & $0.21(-0.01$ to 0.44$)$ & 66.2 \\
\hline Rowing & $1(1)$ & 0.0 & & & $0.08(-0.8$ to 0.96$)$ & 4.7 \\
\hline Overall & $19(20)$ & 0.0 & & & $0.18(-0.01$ to 0.37$)$ & 100.0 \\
\hline \multicolumn{7}{|l|}{ Other parameters } \\
\hline Maximal power & $4(5)$ & 0.0 & & — & $0.45(0.03$ to 0.88$)$ & 100.0 \\
\hline Time to exhaustion & $4(5)$ & 0.0 & & - & $0.14(-0.22$ to 0.5$)$ & 100.0 \\
\hline Ventilatory threshold & $10(11)$ & 22.2 & & - & $0.22(-0.05$ to 0.5$)$ & 100.0 \\
\hline \multicolumn{7}{|c|}{ T1 control vs T0 control } \\
\hline \multicolumn{7}{|l|}{ VO2 $\max$} \\
\hline \multicolumn{7}{|l|}{ by unit of measure } \\
\hline $\begin{array}{l}\mathrm{mL} / \mathrm{kg} / \mathrm{min} \\
\mathrm{L} / \mathrm{min}\end{array}$ & $10(11)$ & 0.0 & & & $0.26(-0.02$ to 0.54$)$ & $\begin{array}{l}100.0 \\
100.0\end{array}$ \\
\hline \multirow{2}{*}{\multicolumn{7}{|c|}{ by training }} \\
\hline & $5(6)$ & & & $-\infty$ & & 27.0 \\
\hline Cycling & $12(12)$ & 0.0 & & $\longrightarrow$ & $0.35(0.11$ to 0.59$)$ & 67.8 \\
\hline Rowing & $1(1)$ & 0.0 & & $-\infty$ & $0.15(-0.73$ to 1.03$)$ & 5.2 \\
\hline Overall & $18(19)$ & 0.0 & & 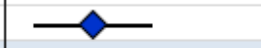 & $0.30(0.1$ to 0.5$)$ & 100.0 \\
\hline \multicolumn{7}{|l|}{ Other parameters } \\
\hline Maximal power & $2(2)$ & 0.0 & & $-\infty$ & $0.41(-0.11$ to 0.94$)$ & 100.0 \\
\hline Time to exhaustion & $3(4)$ & 0.0 & & $-\infty$ & $0.24(-0.15$ to 0.62$)$ & 100.0 \\
\hline Ventilatory threshold & $8(9)$ & $\quad 25.9$ & & 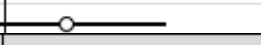 & $0.21(-0.13$ to 0.55$)$ & 100.0 \\
\hline \multicolumn{7}{|c|}{ TO creat vs TO control } \\
\hline \multicolumn{7}{|l|}{ VO2 max } \\
\hline \multicolumn{7}{|l|}{ by unit of measure } \\
\hline $\mathrm{L} / \mathrm{min}$ & $9(10)$ & 0.0 & & - & $-0.13(-0.4$ to 0.14$)$ & 100.0 \\
\hline by training & & & & & & \\
\hline Running & $5(6)$ & 0.0 & & $-\infty$ & $0.12(-0.24$ to 0.49$)$ & 29.1 \\
\hline Cycling & $12(12)$ & 0.0 & 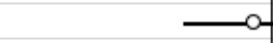 & - & $-0.06(-0.3$ to 0.18$)$ & 66.0 \\
\hline Rowing & $1(1)$ & 0.0 & & & $0.00(-0.88$ to 0.88$)$ & 4.9 \\
\hline Overall & $18(19)$ & 0.0 & & - & $-0.01(-0.2$ to 0.19$)$ & 100.0 \\
\hline Other parameters & & & & & & \\
\hline Maximal power & $3(3)$ & 0.0 & $-\infty$ & & $-0.15(-0.6$ to 0.3$)$ & 100.0 \\
\hline Time to exhaustion & $4(5)$ & 0.0 & & & $0.00(-0.36$ to 0.36$)$ & 100.0 \\
\hline Ventilatory threshold & $10(11)$ & $\quad 31.1$ & $\longrightarrow$ & - & $-0.07(-0.37$ to 0.23$)$ & 100.0 \\
\hline & & & -0.3 & 0.2 & & \\
\hline
\end{tabular}


S6 Appendix. Meta-analyses of aerobic measures at baseline and at T1 between groups, and between T0 and T1 within groups in young and healthy.

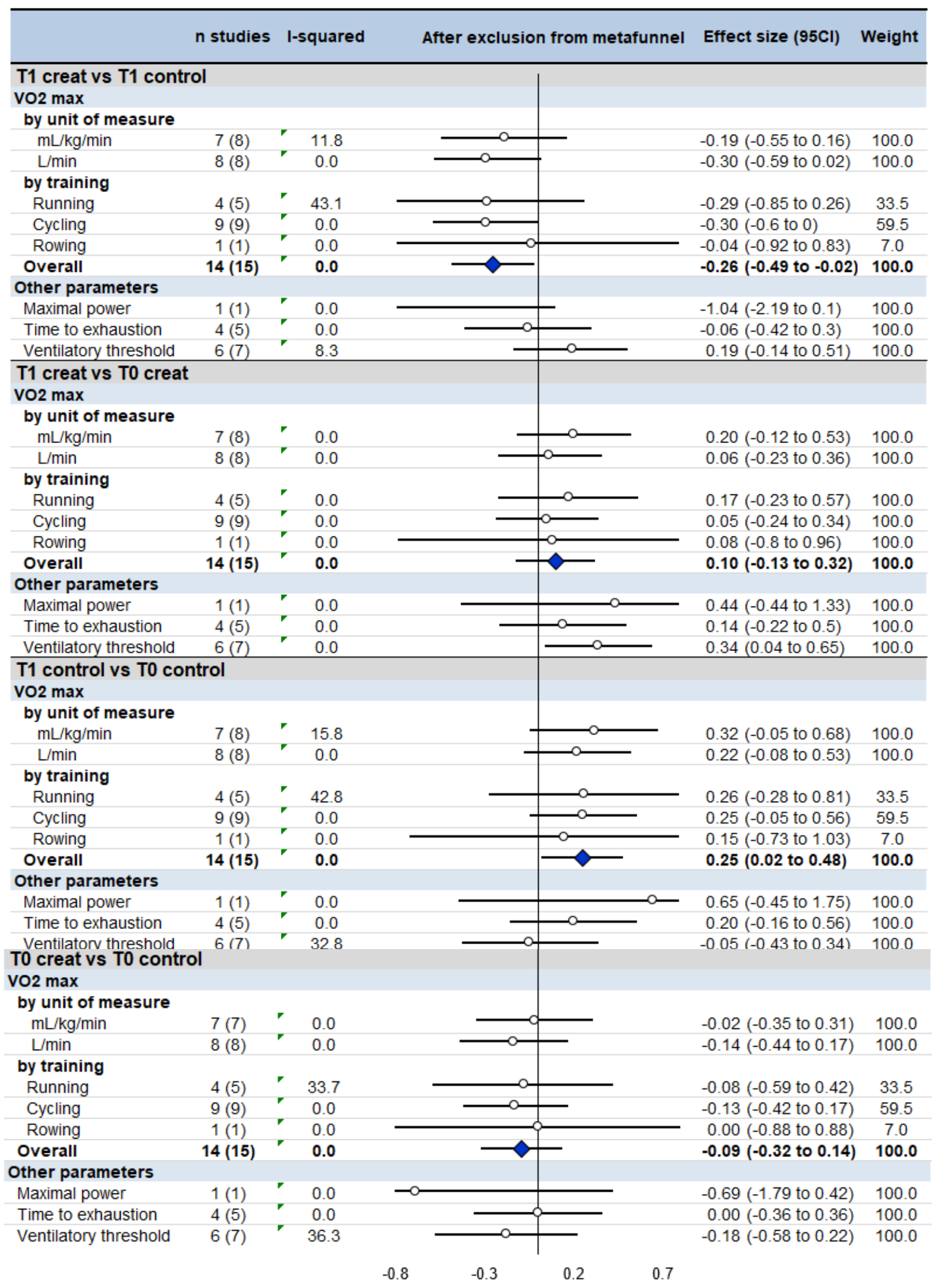


S7 Appendix. PRISMA Checklist.

\begin{tabular}{|c|c|c|c|}
\hline Section/topic & $\#$ & Checklist item & $\begin{array}{l}\text { Reported on page } \\
\#\end{array}$ \\
\hline \multicolumn{4}{|l|}{ TITLE } \\
\hline Title & 1 & Identify the report as a systematic review, meta-analysis, or both. & 17 \\
\hline \multicolumn{4}{|l|}{ ABSTRACT } \\
\hline Structured summary & 2 & $\begin{array}{l}\text { Provide a structured summary including, as applicable: background; objectives; data sources; study } \\
\text { eligibility criteria, participants, and interventions; study appraisal and synthesis methods; results; } \\
\text { limitations; conclusions and implications of key findings; systematic review registration number. }\end{array}$ & 19 \\
\hline \multicolumn{4}{|l|}{ INTRODUCTION } \\
\hline Rationale & 3 & Describe the rationale for the review in the context of what is already known. & $20-21$ \\
\hline Objectives & 4 & $\begin{array}{l}\text { Provide an explicit statement of questions being addressed with reference to participants, } \\
\text { interventions, comparisons, outcomes, and study design (PICOS). }\end{array}$ & 21 \\
\hline \multicolumn{4}{|l|}{ METHODS } \\
\hline $\begin{array}{l}\text { Protocol and } \\
\text { registration }\end{array}$ & 5 & $\begin{array}{l}\text { Indicate if a review protocol exists, if and where it can be accessed (e.g., Web address), and, if } \\
\text { available, provide registration information including registration number. }\end{array}$ & - \\
\hline Eligibility criteria & 6 & $\begin{array}{l}\text { Specify study characteristics (e.g., PICOS, length of follow-up) and report characteristics (e.g., years } \\
\text { considered, language, publication status) used as criteria for eligibility, giving rationale. }\end{array}$ & 21 \\
\hline Information sources & 7 & $\begin{array}{l}\text { Describe all information sources (e.g., databases with dates of coverage, contact with study authors } \\
\text { to identify additional studies) in the search and date last searched. }\end{array}$ & 21 \\
\hline Search & 8 & $\begin{array}{l}\text { Present full electronic search strategy for at least one database, including any limits used, such that } \\
\text { it could be repeated. }\end{array}$ & 21 and S1 Appendix \\
\hline Study selection & 9 & $\begin{array}{l}\text { State the process for selecting studies (i.e., screening, eligibility, included in systematic review, and, } \\
\text { if applicable, included in the meta-analysis). }\end{array}$ & $21-22$ \\
\hline Data collection process & 10 & $\begin{array}{l}\text { Describe method of data extraction from reports (e.g., piloted forms, independently, in duplicate) } \\
\text { and any processes for obtaining and confirming data from investigators. }\end{array}$ & 22 \\
\hline
\end{tabular}




\begin{tabular}{|c|c|c|c|}
\hline Data items & 11 & $\begin{array}{l}\text { List and define all variables for which data were sought (e.g., PICOS, funding sources) and any } \\
\text { assumptions and simplifications made. }\end{array}$ & 22 \\
\hline $\begin{array}{l}\text { Risk of bias in individual } \\
\text { studies }\end{array}$ & 12 & $\begin{array}{l}\text { Describe methods used for assessing risk of bias of individual studies (including specification of } \\
\text { whether this was done at the study or outcome level), and how this information is to be used in any } \\
\text { data synthesis. }\end{array}$ & $22-23$ \\
\hline Summary measures & 13 & State the principal summary measures (e.g., risk ratio, difference in means). & $23-24$ \\
\hline Synthesis of results & 14 & $\begin{array}{l}\text { Describe the methods of handling data and combining results of studies, if done, including } \\
\text { measures of consistency }\left(e . g ., I^{2}\right) \text { for each meta-analysis. }\end{array}$ & $23-24$ \\
\hline $\begin{array}{l}\text { Risk of bias across } \\
\text { studies }\end{array}$ & 15 & $\begin{array}{l}\text { Specify any assessment of risk of bias that may affect the cumulative evidence (e.g., publication } \\
\text { bias, selective reporting within studies). }\end{array}$ & $23-24$ \\
\hline Additional analyses & 16 & $\begin{array}{l}\text { Describe methods of additional analyses (e.g., sensitivity or subgroup analyses, meta-regression), if } \\
\text { done, indicating which were pre-specified. }\end{array}$ & $23-24$ \\
\hline \multicolumn{4}{|l|}{ RESULTS } \\
\hline Study selection & 17 & $\begin{array}{l}\text { Give numbers of studies screened, assessed for eligibility, and included in the review, with reasons } \\
\text { for exclusions at each stage, ideally with a flow diagram. }\end{array}$ & 24 and Figure 1 \\
\hline Study characteristics & 18 & $\begin{array}{l}\text { For each study, present characteristics for which data were extracted (e.g., study size, PICOS, } \\
\text { follow-up period) and provide the citations. }\end{array}$ & 24-27 and Table 1 \\
\hline $\begin{array}{l}\text { Risk of bias within } \\
\text { studies }\end{array}$ & 19 & $\begin{array}{l}\text { Present data on risk of bias of each study and, if available, any outcome level assessment (see item } \\
\text { 12). }\end{array}$ & $\begin{array}{l}24 \text { and Figure } 2, \mathrm{~S} 2 \\
\text { Appendix }\end{array}$ \\
\hline $\begin{array}{l}\text { Results of individual } \\
\text { studies }\end{array}$ & 20 & $\begin{array}{l}\text { For all outcomes considered (benefits or harms), present, for each study: (a) simple summary data } \\
\text { for each intervention group (b) effect estimates and confidence intervals, ideally with a forest plot. }\end{array}$ & $\begin{array}{l}24-27 \text { and S3 } \\
\text { Appendix }\end{array}$ \\
\hline Synthesis of results & 21 & $\begin{array}{l}\text { Present results of each meta-analysis done, including confidence intervals and measures of } \\
\text { consistency. }\end{array}$ & $\begin{array}{l}\text { 27-28 and Figures } 3- \\
4 \text { and S4-S6 Appendix }\end{array}$ \\
\hline $\begin{array}{l}\text { Risk of bias across } \\
\text { studies }\end{array}$ & 22 & Present results of any assessment of risk of bias across studies (see Item 15). & $27-28$ and Figure 5 \\
\hline Additional analysis & 23 & $\begin{array}{l}\text { Give results of additional analyses, if done (e.g., sensitivity or subgroup analyses, meta-regression } \\
\text { [see Item 16]). }\end{array}$ & $\begin{array}{l}\text { 27-28 and S5-6 } \\
\text { Appendix }\end{array}$ \\
\hline \multicolumn{4}{|l|}{ DISCUSSION } \\
\hline Summary of evidence & 24 & $\begin{array}{l}\text { Summarize the main findings including the strength of evidence for each main outcome; consider } \\
\text { their relevance to key groups (e.g., healthcare providers, users, and policy makers). }\end{array}$ & $28-33$ \\
\hline
\end{tabular}




\begin{tabular}{|l|l|l|l|}
\hline Limitations & 25 & $\begin{array}{l}\text { Discuss limitations at study and outcome level (e.g., risk of bias), and at review-level (e.g., } \\
\text { incomplete retrieval of identified research, reporting bias). }\end{array}$ & $33-34$ \\
\hline Conclusions & 26 & $\begin{array}{l}\text { Provide a general interpretation of the results in the context of other evidence, and implications for } \\
\text { future research. }\end{array}$ & 34 \\
\hline \hline FUNDING & 27 & $\begin{array}{l}\text { Describe sources of funding for the systematic review and other support (e.g., supply of data); role } \\
\text { of funders for the systematic review. }\end{array}$ & $35-39$ \\
\hline Funding
\end{tabular}

From: Moher D, Liberati A, Tetzlaff J, Altman DG, The PRISMA Group (2009). Preferred Reporting Items for Systematic Reviews and Meta-Analyses: The PRISMA Statement. PLoS Med 6(6): e1000097. doi:10.1371/journal.pmed1000097

For more information, visit: www.prisma-statement.org 


\section{Conclusion}

La supplémentation en créatine a un effet négatif sur la $\mathrm{VO}_{2}$ max, indépendamment de la méthode de supplémentation, des modalités d'entraînement et des caractéristiques de la population. Considérant que la créatine est le complément diététique le plus largement utilisé dans la pratique sportive, une attention particulière doit être portée vis-à-vis de son utilisation par les sujets pratiquant une activité sportive d'endurance.

Clermont-Ferrand, le

Pierre CLAVELOU

Doyen - Directeur
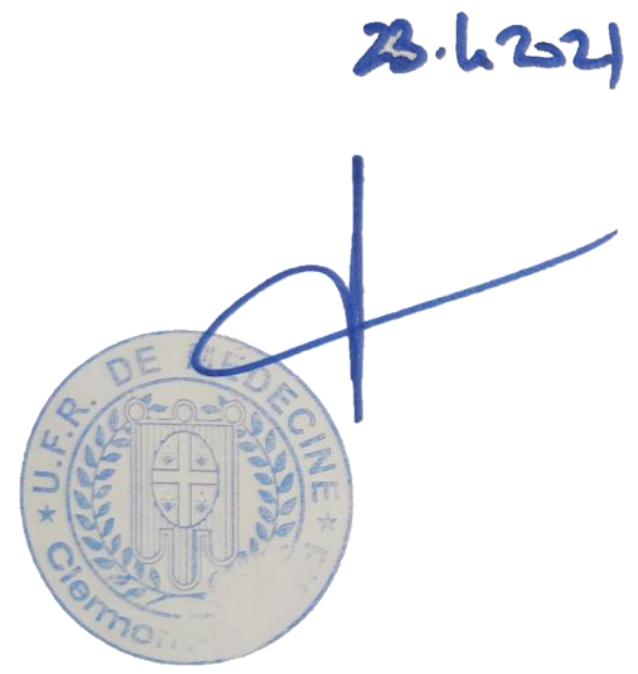

Clermont-Ferrand, le

Le Président du Jury

2210412021
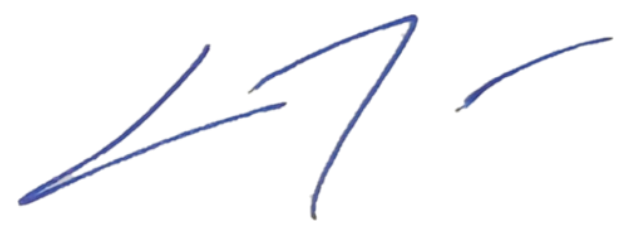


\section{SERMENT D'HIPPOCRATE}

Au moment d'être admis(e) à exercer la médecine, je promets et je jure d'être fidèle aux lois de l'honneur et de la probité.

Mon premier souci sera de rétablir, de préserver ou de promouvoir la santé dans tous ses éléments, physiques et mentaux, individuels et sociaux.

Je respecterai toutes les personnes, leur autonomie et leur volonté, sans aucune discrimination selon leur état ou leurs convictions. J'interviendrai pour les protéger si elles sont affaiblies, vulnérables ou menacées dans leur intégrité ou leur dignité. Même sous la contrainte, je ne ferai pas usage de mes connaissances contre les lois de l'humanité.

J'informerai les patients des décisions envisagées, de leurs raisons et de leurs conséquences.

Je ne tromperai jamais leur confiance et n'exploiterai pas le pouvoir hérité des circonstances pour forcer les consciences.

Je donnerai mes soins à l'indigent et à quiconque me les demandera. Je ne me laisserai pas influencer par la soif du gain ou la recherche de la gloire.

Admis(e) dans l'intimité des personnes, je tairai les secrets qui me seront confiés. Reçu(e) à l'intérieur des maisons, je respecterai les secrets des foyers et ma conduite ne servira pas à corrompre les mœurs.

Je ferai tout pour soulager les souffrances. Je ne prolongerai pas abusivement les agonies. Je ne provoquerai jamais la mort délibérément.

Je préserverai l'indépendance nécessaire à l'accomplissement de ma mission. Je n'entreprendrai rien qui dépasse mes compétences. Je les entretiendrai et les perfectionnerai pour assurer au mieux les services qui me seront demandés.

J'apporterai mon aide à mes confrères ainsi qu'à leurs familles dans l'adversité.

Que les hommes et mes confrères m'accordent leur estime si je suis fidèle à mes promesses ; que je sois déshonoré(e) et méprisé(e) si j’y manque. 


\section{SERMENT D'HIPPOCRATE}

En présence des Maîtres de cette FACULTE et de mes chers CONDISCIPLES, je promets et je jure d'être fidèle aux lois de l'Honneur et de la Probité dans l'exercice de la Médecine.

Je donnerai mes soins gratuits à l'indigent et je n'exigerai jamais un salaire au-dessus de mon travail. Admis dans l'intérieur des maisons, mes yeux ne verront pas ce qui s'y passe, ma langue taira les secrets qui me seront confiés et mon état ne servira pas à corrompre les mœurs ni à favoriser le crime.

Respectueux et reconnaissant envers mes MAÎTRES, je rendrai à leurs enfants l'instruction que j'ai reçue de leurs pères.

Que les HOMMES m'accordent leur estime si je suis fidèle à mes promesses. Que je sois couvert d'OPPROBRE et méprisé de mes confrères si j'y manque. 


\section{Supplémentation en créatine et VO2max :}

\section{Revue systématique et méta-analyse}

Contexte: Malgré les bénéfices admis d'une supplémentation en créatine sur la force musculaire, ses effets sur l'endurance et en particulier la $\mathrm{VO}_{2}$ max sont plus controversés.

Objectifs: Conduire une revue systématique et une méta-analyse des effets de la supplémentation en créatine sur la $\mathrm{VO}_{2} \max$.

Méthodes: Une recherche bibliographique des essais randomisés contrôlés (RCTs) mesurant la $\mathrm{VO}_{2} \mathrm{max}$ avant et après supplémentation en créatine ou placebo a été réalisée depuis les bases de données PubMed, Cochrane, Embase et ScienceDirect. Nous avons conduit 5 méta-analyses principales déterminant les tailles d'effet (ES) sur la $\mathrm{VO}_{2}$ max de la supplémentation en créatine par rapport à un placebo avant supplémentation afin d'évaluer la comparabilité des groupes, après la supplémentation entre les groupes et sur les changements des niveaux de $\mathrm{VO}_{2}$ max entre les groupes et au sein de chaque groupe. Des analyses de sensibilité ont été menées après exclusion des études pouvant présenter un biais de publication et sur un sous-groupe d'individus jeunes et sans pathologie. Des métarégressions ont été conduites pour identifier des facteurs pouvant influencer la $\mathrm{VO}_{2}$ max.

Résultats: 19 RCTs ont été incluses pour un total de 424 individus (âge moyen de 29 ans, 82\% d'hommes). La $\mathrm{VO}_{2} \mathrm{max}$ ne différait pas entre les groupes créatine et placebo avant le début de l'intervention. Les deux groupes bénéficiaient d'un entrainement dans la plupart des études (80\%). La meta-analyse des mesures de $\mathrm{VO}_{2}$ max avant et après supplémentation retrouvait une augmentation de $\mathrm{VO}_{2}$ max dans les deux groupes mais une augmentation moindre avec la supplémentation en créatine par rapport au placebo (ES -0.30, IC95\% -0.50 à -0.11). La comparaison de $\mathrm{VO}_{2}$ max après supplémentation entre les groupes a confirmé une $\mathrm{VO}_{2}$ max plus faible dans le groupe créatine $(-0.20,-0.39$ à -0.001). Les analyses de sensibilité ont donné des résultats similaires sur $\mathrm{VO}_{2} \max$ y compris dans le sous-groupe de sujets jeunes et sans pathologie. Le seuil ventilatoire est augmenté uniquement chez les sujets jeunes $(0.66,0.23$ à 1.1) après supplémentation en créatine. Les méta-régressions sur les caractéristiques sociodémographiques, de l'entraînement et de la supplémentation n'étaient pas significatives.

Conclusion: La supplémentation en créatine a un effet négatif sur la $\mathrm{VO}_{2}$ max quel que soient les caractéristiques de la population, l'entraînement pratiqué ou la méthode de supplémentation.

Mots clés: complément alimentaire, endurance, capacité cardio-respiratoire, $\mathrm{VO}_{2}$ peak, seuil ventilatoire. 